\title{
1 IN SEARCH OF A PALEOLITHIC SILK ROAD IN KAZAKHSTAN
}

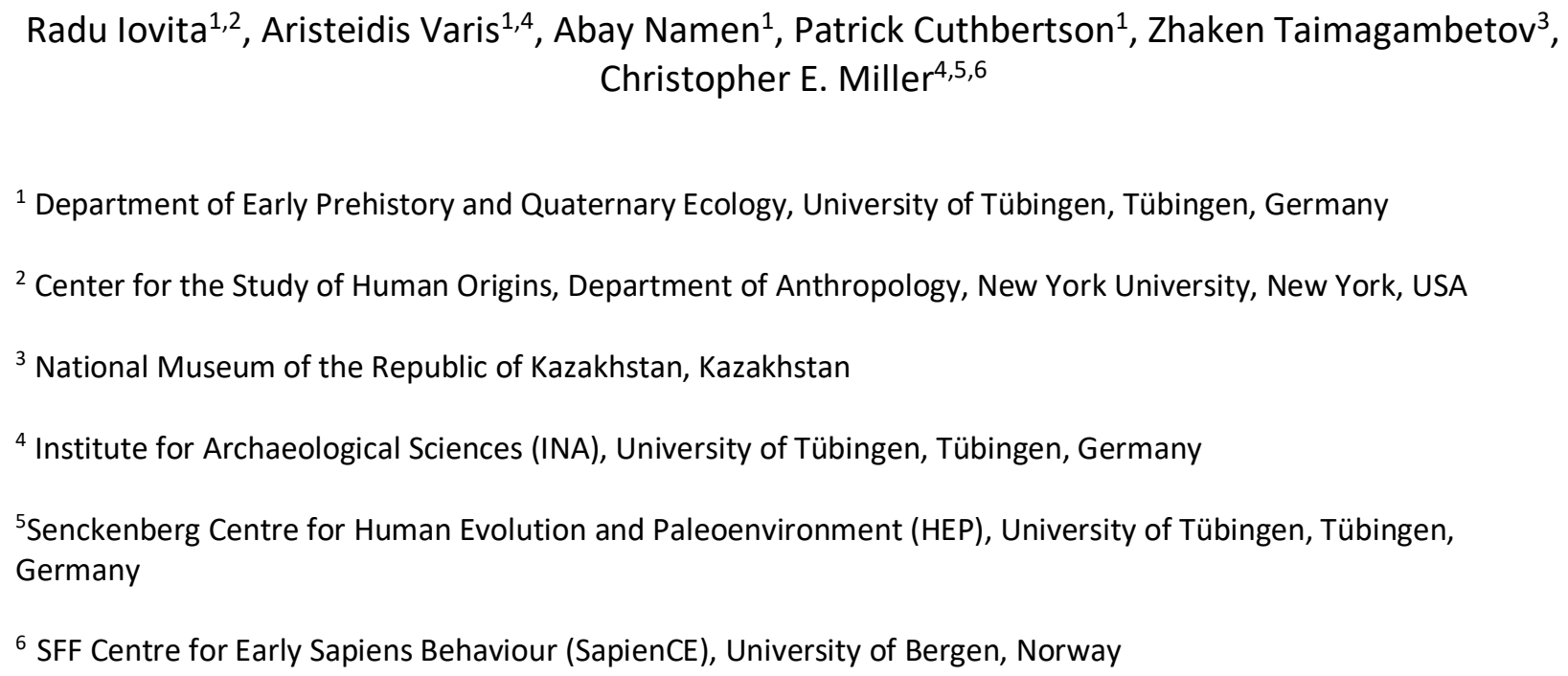

\section{Abstract}

Paleoanthropological data suggest that the Late Pleistocene was a time of population contact and possibly dispersal in Central Asia. Geographic and paleoclimatic data suggest that a natural corridor through Kazakhstan linked areas to the north and east (Siberia, China) to those further to the west and south (Uzbekistan), much akin to a Paleolithic Silk Road. We review the known Pleistocene archaeology and paleoclimatic setting of this region and provide a geoarchaeological framework for contextualizing preliminary survey results of the PALAEOSILKROAD project's first three seasons of fieldwork. We discuss some systematic biases in three geomorphic and sedimentary archives: karst, loess, and spring deposits, specifying ways in which these biases might determine the kinds of data that are extractable by systematic survey. In particular, we caution about the possibility of future systematic biases in chronology that could come about as a result of the type of geomorphic context in which the sites are recovered. We conclude with recommendations for future work in the area. 


\section{Regional setting: The Silk Road in the Late Pleistocene}

The Silk Road was an ancient network of trade routes that constituted the economic, cultural, and biological link between the Middle East and East Asia for at least a millennium during late antiquity and the early Middle Ages. To avoid crossing the deserts and high mountains of arid central Asia - one of the driest regions in the world travelers used the more temperate corridors through the mountain foothills (piedmonts) (Figure 1). Recent research has shown that the movements of pastoral nomads during the Bronze and Iron Ages also reflected a connectivity of these same pathways through the piedmonts (Frachetti et al., 2017). In this paper, we will argue that at least some of these corridors must have been used by people still earlier, in the Paleolithic (for a similar hypothesis further west on the Silk Road, see Nasab et al., 2013). We will review the current state of knowledge on the Stone Age archaeology of the Kazakh piedmonts, and provide a geoarchaeological context for current and future survey work.

\subsection{Central Asia as a crossroads for Paleolithic populations}

An explosion of recent paleogenomic research, along with new techniques for identifying fossil human bone fragments from archaeological contexts have given us new data on the timing of modern humans' arrival and colonization of the inner parts of Asia. Moreover, there is now evidence of multiple encounters (for a review, see Gokcumen, 2019) between the (so far) three different metapopulations, the Neanderthals, Denisovans, and modern humans. Where exactly these encounters took place is not clear, but the amount of time spent in chrono-spatial overlap between them is large enough that the entire territory of central Asia is a possibility (see also Boivin et al., 2013).

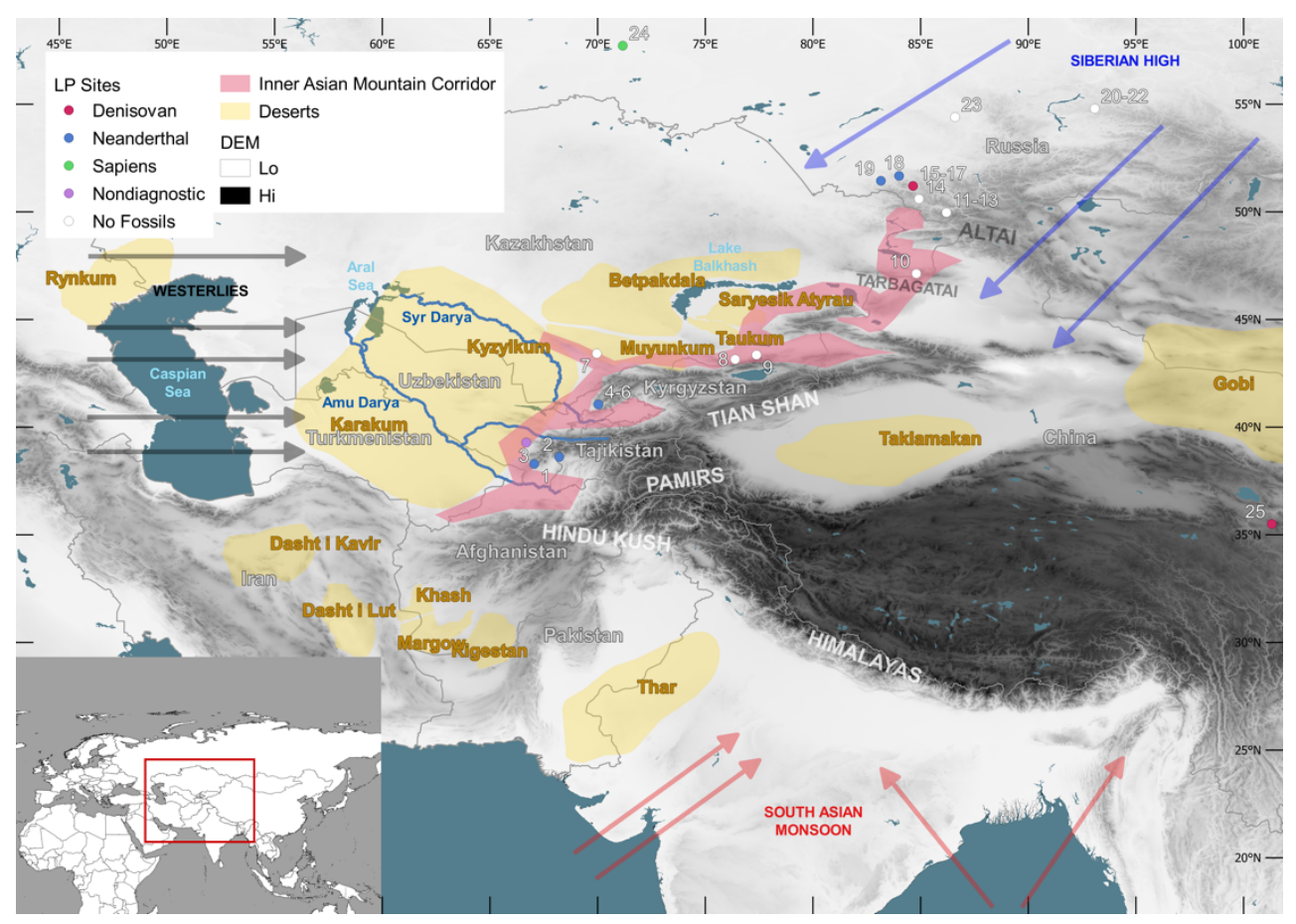

Figure 1 Late Pleistocene sites in and around central Asia, shown in relation to major topography, deserts, and the area of the proposed Inner Asian Mountain Corridor (IAMC). Also shown is the opposition of the Westerlies to the seasonal weather systems 
of the Siberian High Pressure System and the South-Asian Monsoon. 1) Teshik-Tash, 2) Khudji, 3) Anghilak, 4-6) Kulbulak, Obi Rakhmat, Katta Sai, 7) Valikhanova, 8) Maibulak, 9) Rahat 1, 10) Ushbulaq, 11-13) Malo Yaloman, Kara-Bom, Kara-Tenesh, 14) Ust'-Kan, 15-17) Denisova, Ust-Karakol 1, Anui, 18) Okladnikov Cave, 19) Chagyrskaya, 20-22) Ust'-Maltat 2, Derbina 4 \& 5, 23) Mokhovo 2, 24) Ust'-Ishim, 25) Xiahe. Data sources: Global Administrative Areas (GADM) (Hijmans, 2012), vector and raster map data from Natural Earth (naturalearthdata.com) and Shuttle Radar Topography Mission (SRTM) Version 4 (Jarvis et al., 2008).

Likewise, the antiquity of the supposed modern human migrations has been greatly stretched by the new data (Martinón-Torres et al., 2017). A pattern is emerging whereby the earliest modern human fossil dates are furthest east in China (at Daoxian, ca 80 ka, Liu et al., 2015) and the later ones in Siberia (Baigara, Kuzmin et al., 2009; Ust'Ishim, Fu et al., 2014) and Mongolia (Salkhit, Devièse et al., 2019). A possible explanation for that could be a fast, southern coastal route into Asia (James and Petraglia, 2005; Reyes-Centeno et al., 2014), followed by a slower, 'northern route' through Central Asia (Zwyns et al., 2019). Items of portable art and jewellery appear in the Upper Paleolithic repertoires of sites in southern Siberia and Mongolia (Rybin, 2014; Zwyns et al., 2019) and, combined with some characteristics of the lithic assemblages, have been interpreted by several researchers as documenting the first modern human presence in northeast Asia. There is debate about whether modern humans arrived first in Siberia and Mongolia (and how) and then entered China via the Dzhungar Gate (Derevianko et al., 2012) or if they came north through central Asia and Kazakhstan first. One particular difficulty is posed by the fact that so far, all the fossils discovered in Central Asia are of extinct, archaic humans. This means that any modern humans going north and east must have gone through a territory that was already occupied. The details of these movements remain so far completely unknown, largely due to the comparative lack of systematic, large-scale work in the region connecting Fergana and the Altai via the high mountain chains (Tian Shan and Dzhungarian Alatau)(Fitzsimmons et al., 2017).

It is also worth mentioning that not only modern humans are on the move. The new Denisovan fossil from Tibet (Chen et al., 2019), indicates how little we know about these populations' movements in the earlier part of the record. Given its landscape position, at over 3000 m.a.s.l., the Baishiya Karst Cave find (Xiahe, Tibet) raises questions about the Denisovans' long term occupation of and adaptations to high mountain environments (Huerta-Sánchez et al., 2014) - and likewise points to our sampling biases in terms of survey strategy. In an attempt to make up for the lack of fossils, several researchers have attributed the appearance of 'Levallois'-like stone industries in China at sites such as Jinsitai (Li et al., 2018a) and Guanyindong (Hu et al., 2019), to Neanderthal migrations, although others disagree on the industrial attribution at Guanyindong (Li et al., 2009; n.d.).

In order to deal with the dearth of data, several authors have used predictive mathematical models to propose various routes taken by hominins. Li et al (2019) used Least Cost Path models to evaluate the likelihood of various competing routes between known sites in the context of both glacial and interstadial climatic conditions. Their approach is interesting particularly for suggesting corridors through deserts such as the Gobi, which have been previously considered barriers to dispersal (Dennell, 2017). Using estimations of ecological tolerance, in particular of low temperature and high aridity, Beeton and colleagues (2014; Glantz et al., 2015) proposed a model in which populations retreat to the foothills of the Altai and Tian Shan during cold periods and expand into the lowlands during warmer and wetter phases. Although these models move the discussion along, it is necessary to point out that they suffer from the poor quality and density of the input data, as many of the archaeological sites used to generate the models suffer from poor chronostratigraphic controls and the paleoenvironmental data is largely extrapolated from regional or even global models, rather than from locally-derived proxies.

\subsection{Physical geography and climate restrict possible pathways}


Adapting to climate change in a region like arid central Asia is a major challenge for humans. Its high mountains and extensive deserts already represent significant geographic barriers to dispersal and habitation. These changes would have been more abrupt and would have had a more powerful effect in the Pleistocene. During cold glacial periods, the high latitude ice sheets and intensification of the Siberian high pressure system would have resulted in a southward movement of the polar front (Machalett et al., 2008). This in turn intensified aridity, reducing still further the habitable area for Paleolithic hominins, who, unlike Silk Road merchants, were on foot and depended on hunting and collectible plant resources. In this context, it is the mountains, and the water sources originating there that made life possible for hominins and animals alike. In particular, the piedmonts of the Pamir - Tian Shan - Dzhungar - Altai chain form an unbroken Inner Asian Mountain Corridor (IAMC, sensu Frachetti, 2012), which extends from Afghanistan to Siberia, sandwiched between the high mountains and the desert plains (see Figure 1). The foothills of the IAMC form a continuous landscape featuring complex topographies shaped by tectonics, offering sheltered micro-climates and rich plant and animal resources, as well as ample opportunities for ambush hunting (King and Bailey, 2006). The landscape in the IAMC is also affected by the local growth and retreat of mountain glaciers (Koppes et al., 2008; Blomdin et al., 2016). However, these events are not always correlated with global climate (for a review, see Owen and Dortch, 2014; also Figure 2). In particular, the growth of glaciers in the Pamir and Tian Shan ranges is driven by moisture availability, rather than lower temperatures (Koppes et al., 2008). This contrasts with the Altai, where temperature is the primary driver (Lehmkuhl et al., 2011). This means that glacier growth, which necessarily would have restricted movement in the high mountains of Central Asia by sealing up mountain passes, does not correlate well with global cold phases.

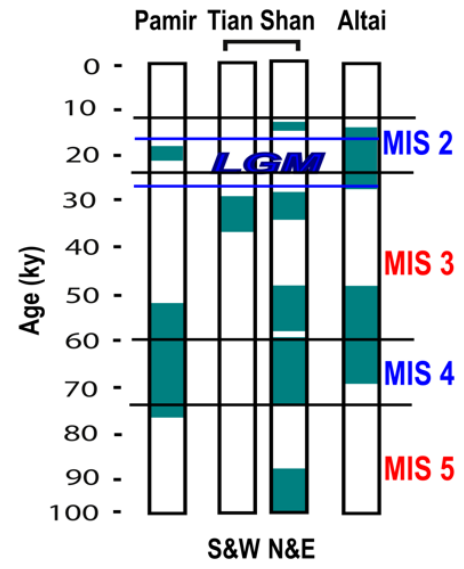

Figure 2 Maximal extent of mountain glaciers in the IAMC (data from Owen and Dortch (2014)). Marine Isotope Stages (MIS) and the Last Glacial Maximum (LGM) shown for context (red = warm (interstadial), blue = cold (stadial)).

\subsection{Known Paleolithic contexts}

As mentioned before, the archaeological data from the Pleistocene IAMC data are scarce. Part of the reason why lies with the history of systematic research. The first finds of individual stone tools can be traced back to the 1850s, when locals found several arrowheads during the excavation of a kurgan in Southern Kazakhstan, and blades were also found on the Mangyshlak Peninsula (Caspian) in 1862 (Chekha, 2017). Similar findings were recorded by Russian geologists in eastern Kazakhstan, where a museum of local history was established in 1883 containing approximately 80 stone tools. During the construction of the Turksib (Turkestan-Siberia) railway in 1928, a large Upper Paleolithic-type core was discovered from the pit at a depth of $2 \mathrm{~m}$ in a locality of Altyn-Kolat, South 
Kazakhstan (Alpysbaev, 1970). Systematic surveys and excavations began in the 1950s, following news of the discoveries made by Okladnikov in Uzbekistan (Ozherelyev, 2007). Khasan Alpysbaev's work concentrated on the South Kazakhstan region, where he discovered abundant surface scatters, as well as a number of cave sites, such as Ushbas and Qaraungir (also known as Karaungur (Taimagambetov and Nokhrina, 1998)). Alan Medoev undertook surveys mainly in the regions around Mangyshlaq, Saryarga, and Lake Balkhash (Alpysbaev, 1961; Medoev, 1964). Their work was continued by Zhaken Taimagambetov (e.g., Taimagambetov, 1983; 1990; 1997; Taimagambetov and Ozherelyev, 2008; 2009), Olga Artyukhova in the Central and Western regions (Artyukhova, 1990; Artyukhova and Mamirov, 2014), and Valeriy Voloshin in Northern Kazakhstan (Voloshin, 1971), along with many collaborators.

Most of the finds reported as sites (Rus.: 'otkrytye mestonahozhdeniya') are surface lithic scatters and cannot be directly radiometrically dated. Assemblage attributions to period and cultural entities are almost always based on lithic typology. Some sites, such as those of Semizbugu (Pribalkhash) (Medoev, 1982), Mangyshlaq (Caspian shore) (Derevianko et al., 1999), and Qyzyltau (Muyunqum/Eastern Karatau border) (Derevianko et al., 2002) represent large accumulations of stone tools in deflated contexts. Others, such as the Batpak (Klapchuk, 1971) sites in central Kazakhstan, are from colluvial or other formerly primary stratified contexts. Only a handful of primary context stratified sites have been discovered and studied across the vast area from the Irtysh to the Karatau range near Shymkent. They can be found in different geomorphic and geological contexts such as loess, river terraces, and in spring deposits (travertine). The earliest sites, of the Qoshqorgan-Shoqtas complex, formerly known as Koshkurgan-Shoktas (Derevianko et al., 2000) are found in travertines in South Kazakhstan. In loess, there are the Upper Paleolithic sites of Valikhanova (Alpysbaev, 1979; Taimagambetov, 1990)) and Maibulaq (Taimagambetov and Ozherelyev, 2008; Taimagambetov, 2009), recently reviewed and re-dated by Fitzsimmons et al. (2017) to the period between roughly 40 and $25 \mathrm{ka}$. The site of Rahat was discovered in the last decade and excavated only in the past several seasons (Ozherelyev et al., 2019), with an OSL chronology pending. In the East Kazakhstan region, only two stratified Upper Paleolithic sites are known, Shul'binka on the Irtysh (Taimagambetov, 1983; 2012), and the recently discovered site of Ushbulaq, on the bank of a spring in the Shilikti Valley near Lake Zaisan (Derevianko et al., 2017). The latter is radiocarbon-dated to $45249-44012$ calBP (Anoikin et al., 2017). Finally, in caves, only one verifiable Pleistocene context is known, from Ushbas in the South Kazakhstan region (recently reexcavated by Grigoriev and Volkov, 1998), which featured a small collection attributed typologically to the Upper Paleolithic.

\section{Possible arChaEOlogical CONTEXTS}

For the preservation and discovery of Paleolithic sites, both deposition (leading to preservation) and exposure (leading to higher visibility) are required. Given the general landscape characteristics and enormity of the landmass of Kazakhstan, this presents a series of unusual challenges. Nevertheless, several patterns emerge: caves and loess present good, if incomplete, archives of past behavior, and spring and river terrace sites bring a variety of opportunities and problems to the table. In our survey, terraces of large rivers have been the least promising of these contexts, so we will limit our discussion to karst, loess, and springs.

\subsection{Karst and pseudokarst}

Caves tend to be a major focus of any archaeological survey strategy, as they generally form good sediment traps corresponding to relatively long time periods and are thus well-suited to sequence-building. Unfortunately, the general characteristics of karst in Kazakhstan are poorly known even when compared with other Central Asian former Soviet republics. Here we focus on specific examples in order to outline some basic geomorphological characteristics of the karst and pseudokarst found in the IAMC of Kazakhstan and evaluate its potential for preserving Pleistocene archaeology. Such an evaluation is crucial for beginning to apply more sophisticaled predictive models of cave site location (for an example of such models, see Heydari, 2007; Märker and HeydariGuran, 2009). 


\subsubsection{Solutional CAVES}

Dissolution of carbonate rocks by circulating meteoric water is the most frequent mechanism for the development of karst landscapes and the formation of solutional caves (Audra and Palmer, 2011). More specifically, the majority of caves are formed by surface flowing water that absorbs carbon dioxide from the atmosphere and the soil, acquiring thus the necessary solution capacity to react chemically with the carbonate bedrock and to form underground conduits. Based on the level of the water table, caves form either in the unsaturated portion of the subsurface (vadose zone) or in the saturated aquifers (phreatic zone). Vertical fluctuations of the water table induced by changes in the base level, result in the development of extensive cave systems that form complex morphological patterns (Palmer, 1991).

In Kazakhstan, the presence of extensive cave systems in a single hydrological catchment seems to be relatively infrequent. In that sense, the occurrence of isolated or single chamber caves that seem to have no genetic relationship to the modern topography (sensu Frumkin and Fischhendler, 2005) are common. In general, the average size of the surveyed caves is small, since they usually represent the enlargement of a single conduit without the development of a network of passageways and chambers. The majority of the surveyed caves are in the later stages of karst evolution and they are characterized by drained passages, wall and ceiling collapse, as well as dissection by surface erosion (Palmer, 2002). Water flow in modern cave passages was encountered only in a few instances, and speleothem formation was also limited. The few speleothems recorded include tiny globular corallite structures known as 'popcorn' and formed under the evaporitic conditions of cave entrances (Self and Hill, 2003; Ford and Williams, 2007, p. 281) and flowstone deposited on cave floors. A few instances of poorly developed stalactites and stalagmites were also recorded. The lack of suitable speleothems for paleoenvironmental and paleoclimatic reconstructions effectively means that the sedimentary sequence preserved in some features constitutes the only cave archive for these types of analyses (White, 2007).

Structural factors seem to play an important role in cave evolution in Kazakhstan. Occasionally, angular walls with straight faces that form triangular entrances and run partially or throughout the depth of the cavities indicate the presence of fault-guided cave development (see Figure 3a). Tectonic stress can also result in plastic (ductile) deformation of rocks, which will eventually lead to the creation of folded but not necessarily displaced strata. This can be seen occasionally via the presence of localized tectonic breccia adjacent to the cave entrance, as in the example shown below (see Figure 3b).

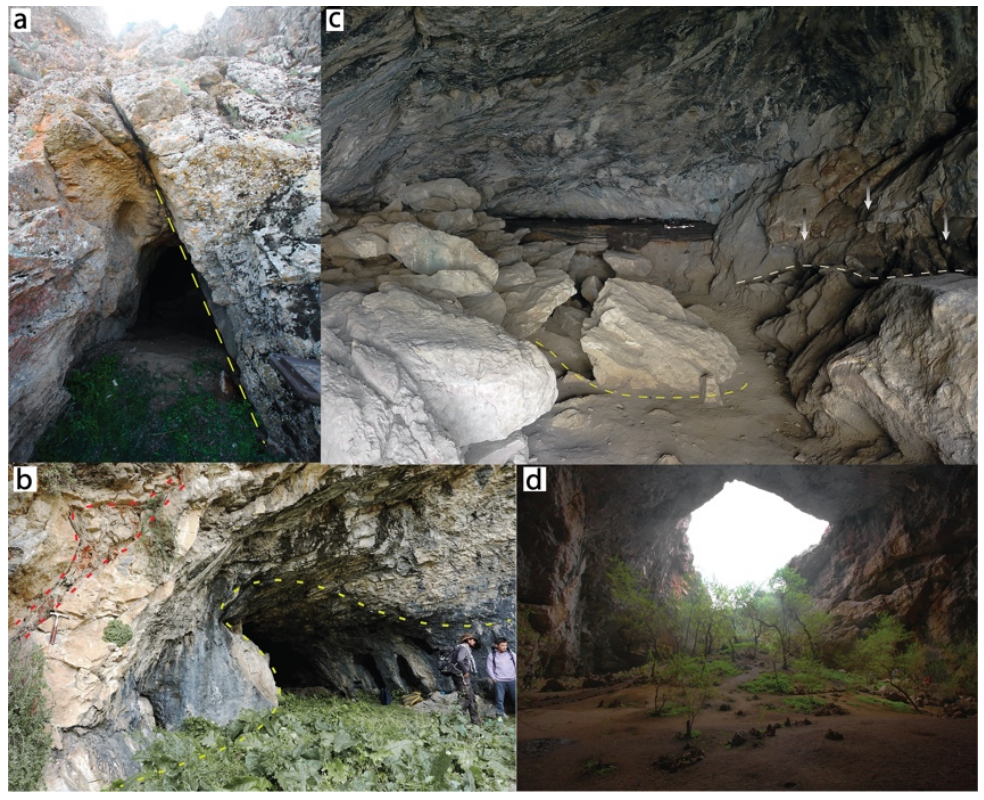


Figure 3 Structural mechanisms affecting cave morphology. A) Ushbas. Yellow dotted line indicates the fault plane parallel to the south wall; slickensides exposed at the face of the fault plane, although not visible from this view, are indicative of vertical displacement (dip-slip fault). B) Marsel. Yellow dotted line, humans for scale; steeply inclined asymmetrical fold acting as the incipient horizon of cave development. Red dotted line, geological hammer for scale; localized matrix-supported tectonic breccia composed of angular carbonate fragments constitutes additional evidence of ductile stress deformation. C) Tuttybulaq 1 . White arrows indicate direction of slumping; white dotted line indicates accumulation of slumped material. Yellow dotted lines indicate major fallen boulders associated with ceiling collapse that cover the middle part of the chamber. Scale in the back of the cave is 1 meter. D) Aqmeshit cave. View towards the collapsed dome at the top part of the cave and the accumulated sediment cone below.

On the other hand, more localized and irregular micro-faulting, most probably associated with secondary earthquake activity, has also led to the subsequent dislocation of rocks from the walls and ceilings of some caves resulting in a change of the available cave space. Structurally-induced changes at the approximately 25-meter long main chamber of Tuttybulaq 1 (Figure 3c) provide a prime example of this process. Here vertical dislocation of parts of the southeast wall, indicated by local slumping and accumulation of massive boulders promoted extensive ceiling collapse. This resulted in the vertical expansion of the main chamber on the one hand, and the sealing of Holocene occupation levels (Baytanaev et al., 2017; 2018) by boulder-sized blocks on the other.

Breakdown is a general characteristic of drained caves because the roof of the passages and chambers loses the hydrostatic support of water (Gillieson, 1996, p. 8). Furthermore, long term stress may lead to the progressive collapse of the cave ceiling resulting in domed caves. The dome is defined as "a large hemispheroidal hollow in the roof of a cave formed by breakdown, which prevents bedding and joints dominating the form" (U. S. EPA, 2002, p. 63). In places where a wide roof span is combined with little rock cover, the collapsed dome gets exposed to the surface revealing the underground cavity (Benson and Yuhr, 2016, p. 80). This probably explains the morphology of Aqmeshit cave, a famous religious cave site located in the Baidibek district of Turkestan region (Figure 3D). The cave is more than $150 \mathrm{~m}$ long, around $30 \mathrm{~m}$ tall and it can only be accessed by a vertical staircase positioned at the highest part of the former ceiling. Following the roof collapse, wind-blown sediment started settling into the exposed chamber building up a sediment cone directly under the dome. Given the possibility of rapid wind-blown sedimentation, it is hard to estimate a minimum age for the collapse of the dome without further survey and analysis. However, the absence of fallen roof rock on the surface and the thickness of the sediment cover indicate that preservation of Pleistocene sediments is possible.

The relationship between tectonics and cave formation observed in the field is confirmed by the pattern of cave location relative to fault lines. For example, in the area of the Lesser Boraldai in the Southern Karatau (Figure 4), a complex of faults intersects the Devonian and early Carboniferous sedimentary rocks resulting in a high relief topography. High escarpments and cliffs feed steep-gradient streams that create deep canyons and ultimately flow into an elongated drainage basin towards the east. At the middle of the basin, the Lesser Boraldai group is formed on the uplifted Devonian complex, with the majority of the cavities mapped directly on the fault line. The Lesser Boraldai group is composed of caves and rockshelters formed on breccia and limestone, with the majority of the features characterized by extensive wall/roof collapse and an absence of accumulated fine sediment. Further to the west, Tuttybulaq 1 (see discussion above and Figure 3C) and 2 are formed in brecciated limestone also intersected by the faults. 


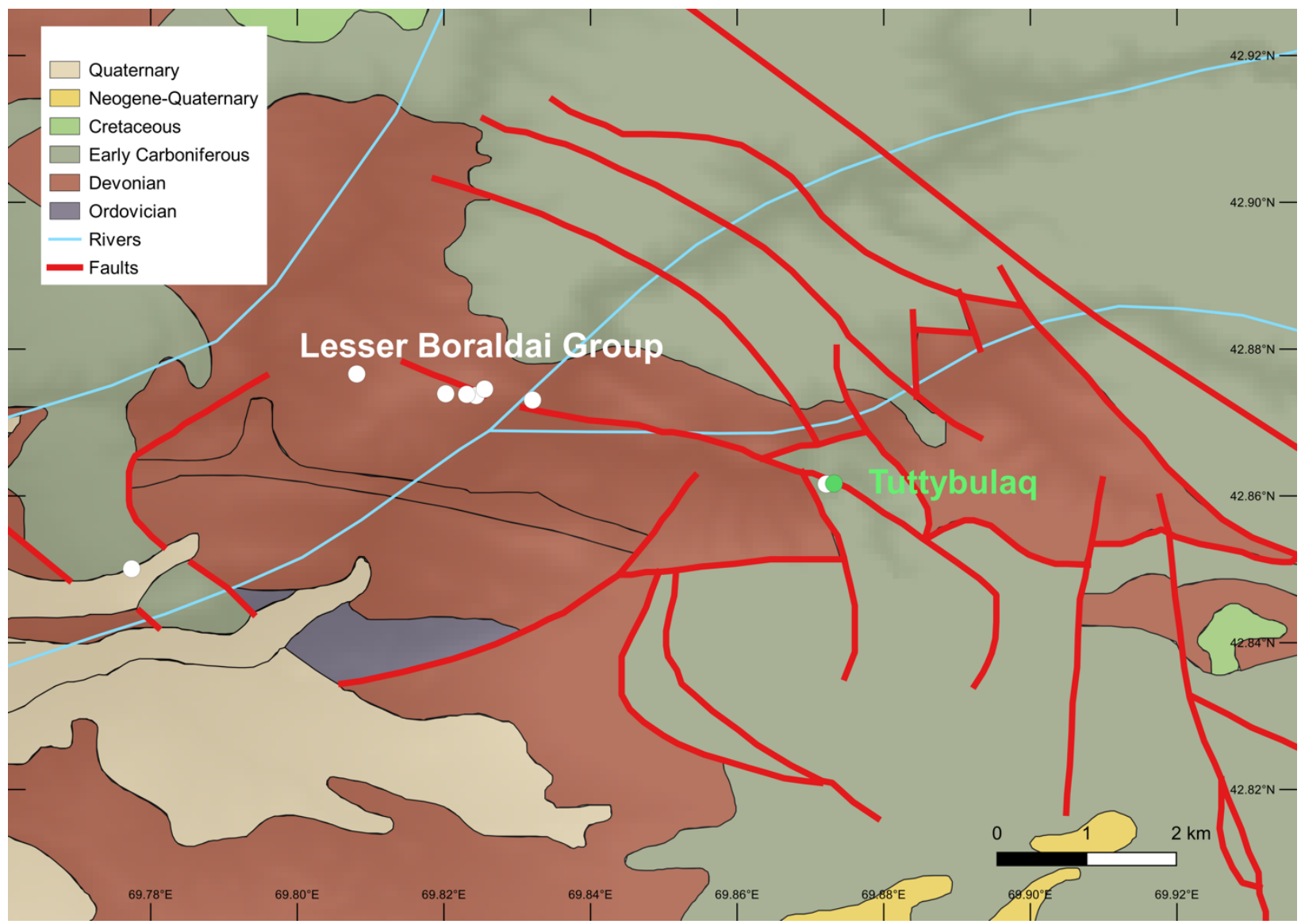

Figure 4 Geology, faults, and rivers surrounding the Lesser Boraldai Group and the Tuttybulaq locality. Data sources: HydroSHEDS (Lehner et al., 2006).; Mineral Deposits Database and Thematic Maps of Central Asia, (Seltmann et al., 2004).

2

\subsubsection{PSEUDOKARST AND NON-KARSTIC PROCESSES}

Pseudokarst is defined as any landform that resembles karst, but it has formed by non-solutional processes (Grimes, 1975). From the various types of pseudokarst that have been documented in different parts of the world (Holler, 2019), small sink holes, gullies and loess cavities formed along slopes constitute the most common feature encountered during our survey in Kazakhstan. Karst-like loess features are attributed to piping erosion, viz. the horizontal or vertical removal of soil or unconsolidated material by concentrated water flow (Halliday, 2007, p. 106). They develop under the impact of steep topography, concave slope morphology and intense precipitation (Verachtert et al., 2010; Bíl and Kubecek, 2012). Based on our observations, loess pseudokarst frequently acted as a death trap for modern animals that were fallen in the sink holes or were buried under partially collapsed cavities. This phenomenon implies that the aforementioned features can act as a context for the possible accumulation of archaeological material. However, in contrast to the relatively stable karst caves and rockshelters, loess is highly erodible and susceptible to slumping and other mass movement processes and are thus very dangerous for researchers (Li et al., 2018b). In this regard, well-developed loess pseudokarst structures are ephemeral (Lukić et al., 2009; Pavuza and Plan, 2013) and therefore constitute unfavorable features for the preservation of archaeological remains in the long-term.

Pseudokarst can also form by lateral fluvial erosion along the course of rivers and streams. It usually develops as a rockshelter or shallow cave morphology in any type of rock, following zones of weakness induced by tectonics or 
lithological variation. Parent rock type and the external geomorphic regime influence the accumulation and preservation of sediment in these features. For example, Nazugum rockshelter (Ketmen range of the Trans-lli Alatau) was initially formed by the lateral eroding action of the Ketmen river system that shaped the intensely dissected volcanic rock highlands. It is located at the foot of a straight cliff not much higher than the current river channel (Figure 5A). Isolated sediment columns that reach up to the ceiling of the rockshelter partially preserve at some places under the brow, revealing that the rockshelter was at some point almost completely filled. However, in the majority of the rockshelter area and especially towards the back of the chamber, sediment cover is absolutely absent and the bedrock is exposed. At the lower part of the stratigraphic sequence, imbricated gravel layers interlaminated with clays and fine sands indicate a period of fluvial deposition and channel widening. This phase was followed by progressive downcutting of the stream's bed and concurrent wind-blown sedimentation in the cavity, as demonstrated by the massive loess deposits that overlie the fluvial layers. The pseudokarstic processes that lead to the active erosion of the sediments are evident by clear morphological features like sediment arches that denote the presence of water channels. These channels flow from the inside of the rockshelter towards the outside and should be attributed to secondary solutional pathways in the parent rock.

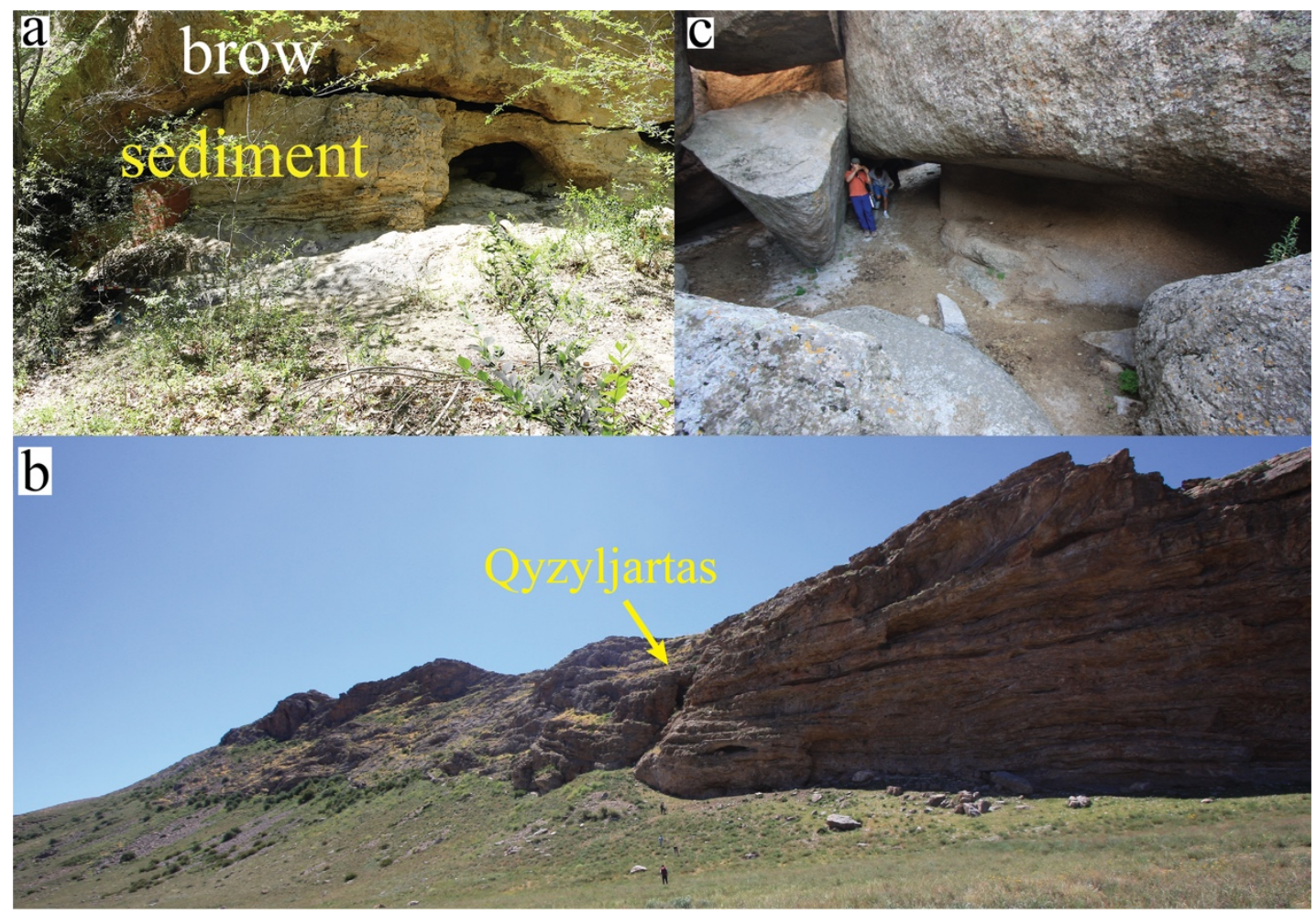

Figure 5. Pseudokarst features and non-karstic processes. A) Nazugum rockshelter. View towards the southern part of the rockshelter where most of the sediment is still preserved. Sediment thickness ca. $2.6 \mathrm{~m}$. Note the sediment arch on the right of the picture indicating active erosion. B) Qyzyljartas. General view of the cave entrance and the adjacent landscape. Note small cavities at multiple points in the outcrop produced by solutional or even aeolian erosion of weak sandstone beds. People for scale. C) Black cave. Curved erosional features produced by stream channels (right side) and mechanical breakdown piling-up boulder-sized clasts (left side). People for scale.

Pseudokarst fluvial features also occur in sandstone, granite and conglomerate. In the absence of allochthonous sedimentation, such as wind-blown loess, the type of parent material, as well as the way it disintegrates and 
accumulates through time, constitute the dominant factors controlling deposition in the cavity. From the above bedrock categories, only those in sandstone were substantially covered by autochthonous geogenic sediments. These fine-grained sediments accumulate rapidly as a result of in situ chemical and mechanical weathering of sandstone. One example of non-karstic processes shaping sandstone features is documented at the cave of Qyzyljartas that lies on the north-eastern side of the Qaratau mountain range. It is situated almost at the top of a medium-bedded sandstone outcrop, which forms a very steep cliff and overlooks an extensive valley filled with loess and dissected by a more recent river (Figure 5B).The cave itself is infilled by a homogeneous sequence of red silty sands, which is interrupted by allochthonous water-lain deposits that in some cases sort out, reshape and redistribute older sediments, leaving behind well-sorted and rounded quartz grains as well as sandstone rip-up clasts. The fluvial deposits are relatively thick and heterogeneous indicating multiple phases of channelized water flow. These sediments should be associated with an older catchment of the valley river system, even though it is currently unclear if they constitute remnants of actual fluvial action at a higher elevation than the modern valley floor. Nevertheless, the presence of water-lain sediments in Qyzyljartas provides an insight into the diverse erosional dynamics that led to the enlargement of the original cavity and could be potentially attributed to a different climatic and drainage regime in the basin.

On the other hand, Black Cave (Kaz. Qaraungir near Taldyqorgan, written here in English translation to distinguish it from the Neolithic site of Qaraungir/Karaungur in the Karatau) is a granitic grotto formed by erosive river action and by the slipping of the giant granite boulders that accumulate as a talus of irregular morphology (Figure 5C). Rock art of most probably Bronze Age on the walls demonstrates human presence and use of space in the feature. However, in comparison with the sandstone example above (Qyzyljartas), Black cave and other granite rockshelters that we recorded are less likely to disintegrate that easily into loose sediment, such as grus (Kajdas et al., 2017), and as a result less probable to accumulate thick autochthonous deposits. Since the rate of surface erosion cannot be surpassed by the rate of geogenic deposition, any artifacts or features deposited in the grotto are less likely to be captured and preserved.

To conclude, locating pseudokarstic features is a challenging task since their occurrence cannot be predicted by a model that is based solely on bedrock classification. However, considering river action as a geomorphological modelling agent, the discovery of these water-cut features may be facilitated from the targeted survey of deep incised canyons and valleys that are not covered by loess.

\subsection{Loess}

Loess is aeolian fine-grained silt that blankets much of the Central Asian piedmonts (see Figure 6). Alternating loess-paleosol (LP) sequences showcase climatic changes from relatively dry and cold periods (represented by the loess) and relatively humid and warm periods (represented by soil formation). Recent research in Kazakhstan has shown that this information can be combined with that drawn from human occupations to create a relatively nuanced picture of human-environment interactions (Machalett et al., 2008; Feng et al., 2011; Fitzsimmons et al., 2017; 2018; Sprafke et al., 2018). Moreover, sites appear to often be located in similar landscape locations, often at the beginning of alluvial fans created by intramontane rivers.

So far, Paleolithic sites preserved in loess deposits in Kazakhstan are all multi-layered and belong to the same time period, the Upper Paleolithic. The multi-layered aspect of sites such as Valikhanova (Taimagambetov, 1990), Maibulak (Taimagambetov and Ozherelyev, 2008), and Rahat (Ozherelyev et al., 2019) is somewhat unusual in the general context of Eurasian Paleolithic sites, where open-air sites often document ephemeral occupations of a particular landscape location. Unlike caves, these open-air locations may reflect unknown and unknowable pragmatic considerations on the part of the ancient inhabitants, some of which may include the presence of trees, proximity to a comparatively sheltered location, or good visibility for stalking animals. In any case, the timing and intensity of occupation should provide a good proxy for occupation patterns during particular time slices. 


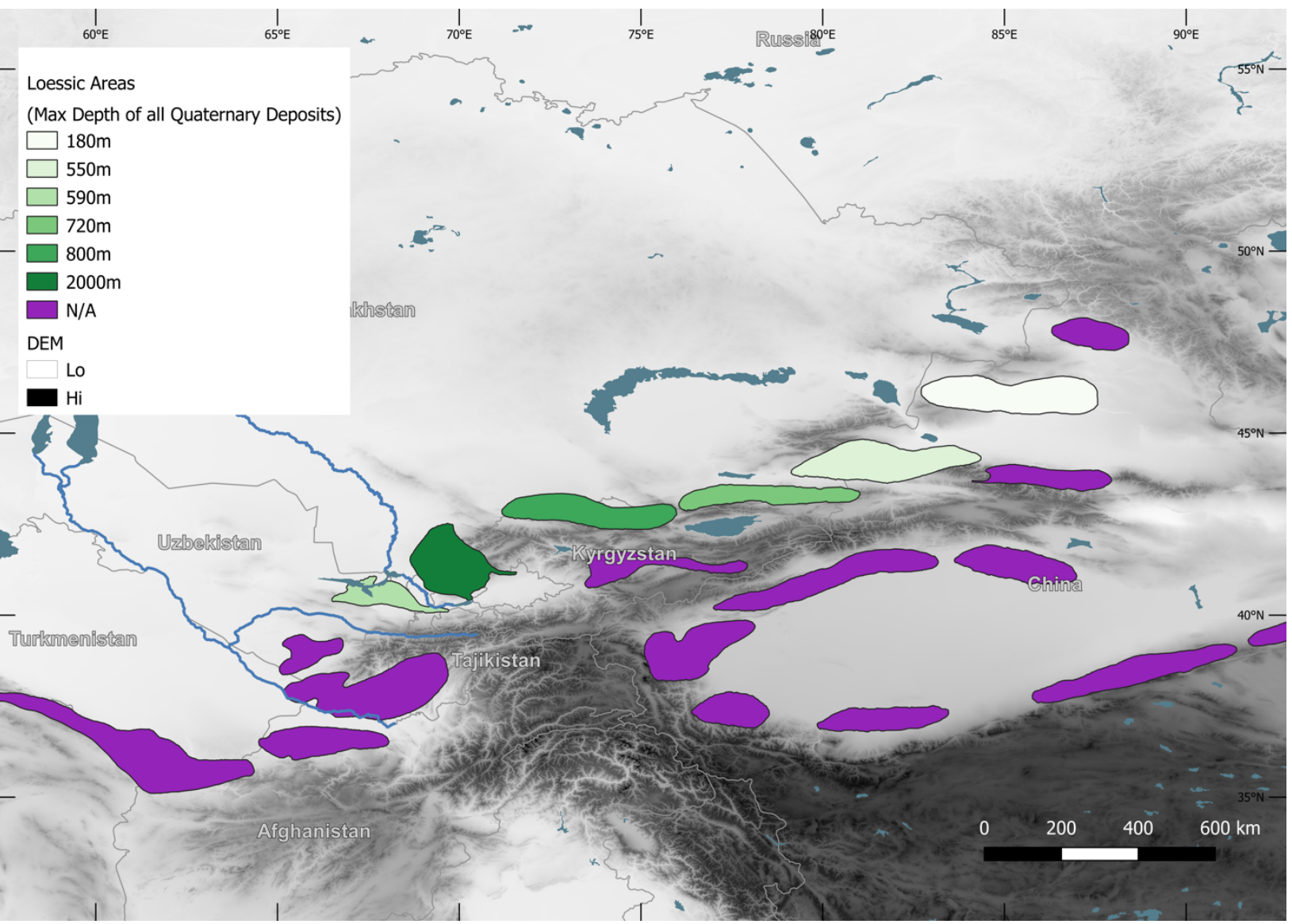

Figure 6. Distribution of loess in Central Asia, after Dodonov (2007). Color denotes maximum thickness of Quaternary deposits in each of the PALAEOSILKROAD study areas. Thickness data are obtained from Soviet geological maps (1:200k). Including data from: Global Administrative Areas (GADM) (Hijmans, 2012) http://www.gadm.org/about, Natural Earth @ naturalearthdata.com, and Shuttle Radar Topography Mission (SRTM) Version 4 (Jarvis et al., 2008) http://srtm.csi.cgiar.org.

\subsection{Springs}

Springs appear at points in the landscape where groundwater intersects with the topography and flows onto the surface. They emerge in various geological and geomorphological settings under the force of gravity and can be classified in numerous types according to their genetic characteristics (Kresic and Stevanović, 2010, chap. 2). They constitute locations of significant ecological contribution since they provide freshwater for animals and humans. Furthermore, in semi-arid areas like Kazakhstan where annual precipitation is low, seasonal or perennial springs provide places of hydrologic refugia during periods of fluctuating climate (Cartwright and Johnson, 2018). The potential role of springs for hominin survival, evolution, and dispersal has been explored with positive results in the arid environments of East Africa (Cuthbert et al., 2017). In this framework, Barboni et al. ( 2019, table 1), catalogue around 50 spring localities and sites associated with Pliocene and Pleistocene paleontological and archaeological remains from Africa to the Middle East.

Previous archaeological research in Southern Kazakhstan documented a handful of open-air sites located in travertine precipitating springs (Derevianko et al., 1998). The sites, which were dated by EPR (electro- 
paramagnetic resonance, a variant of ESR) to ca 500 - $400 \mathrm{ka}$, are concentrated in an area of approximately 100 $\mathrm{km} 2$, in proximity to Koshkurgan/Qoshqorgan village, at the piedmont plain covering the southwest slope of the Karatau Range (Derevianko et al., 1998). The deposition of calcium carbonate by springs constitutes an ideal preservation agent for archaeological horizons by forming travertine crusts over them or by impregnating (cementing) older sediments. Therefore, these processes can lead to the formation of deposits that are less susceptible to erosion by surface agents, and this explains the unique preservation of such ancient remains in a context otherwise devoid of stratified Middle Pleistocene sites. Given that they are not covered by younger sediments, as in the case of the Koshkurgan/Shoktas sites, spring deposits provide visible and relatively stable landscape features. However, the intensity of freshwater carbonate precipitation and accumulation varies among springs. Specifically, it is a function of local geomorphological and environmental factors such as climate, vegetation, soils, topography, bedrock, hydrology and of course time (Viles and Goudie, 1990; Andrews, 2006; Mors et al., 2019). Some springs may deposit carbonates only occasionally (e.g. Smieja and Smieja-Król, 2007) and therefore lack consolidated travertine or tufa deposits. Naturally, this implies that archaeological sites in their vicinity are more exposed to erosion.

The previous discussion highlights springs as a possible target of systematic survey, as they combine obvious resource value to hominins with deposition mechanisms and relatively easy mapping. Moreover, unlike large river valleys, springs are manageable in size and present a better signal-to-noise ratio for spotting artifacts on the surface. No data source is perfect, however, and springs have their drawbacks: for instance, given their fluctuating course, lithics found on the surface at one locality may have been part of a channel that is now extinct, something that can only be checked through coring or test excavations. All in all, however, we predict that springs will eventually provide a good source for finding Paleolithic sites in Kazakhstan.

\section{PRELIMINARY FINDINGS}

In three field seasons from 2017-19, the PALAEOSILKROAD team has conducted around six months of survey, primarily targeting caves and rockshelters, in addition to continuing work at some of the known loess sites (Maibulak and Rahat). Spring sites were surveyed in connection with our karst survey and are discussed in Sections 3.1 and 3.2 below. Given the preliminary nature of our ongoing systematic survey of loess deposits, especially in the foothills of the Tian Shan, we will omit them from our discussion here.

\subsection{Caves and rockshelters}

During the 2017-2019 field seasons, we have located and recorded 95 cave and rockshelter features in our study regions (see Figure 7 and also Table 1 below). Of these 95 features, only ten were previously known, meaning that 85 have been discovered from our survey activity. As it was expected, the vast majority of these are in the Qaratau range, with two other, smaller groups in the Jungarian Alatau and Kazakh Altai. In terms of region, one surprise was the near total absence of prospective caves in the Kazakh Altai, where the presence of carbonates would have predicted a dense presence of suitable cavities. Cave systems in the southeast of Kazakhstan are very poorly known, even to speleologists (Shakalov, 2010), and the majority of the cavities encountered do not have significant amounts of sediment.

The archaeology discovered in the caves is still at a very preliminary stage. Only about a quarter of the caves and rockshelters recorded have some sort of sediment preserved $(n=28)$, although many of those that do contain visible remains of Holocene archaeology. Test excavations were carried out at the 10 most promising localities, and are still ongoing at three of them. In general, the depth of sediments accumulated in the Holocene is quite large, between 1.5 and $2 \mathrm{~m}$, although not enough of them have been excavated down to bedrock to produce a statistically significant sample. When Pleistocene layers have been reached, the surface excavated has so far been too small to result in any obvious cultural or chronological assignations while radiometric dates are in processing. 
The presence of both caves containing sterile and occupied Pleistocene layers, however, is very promising for

future predictions of landscape preference and occupation history in this region during the period of interest.

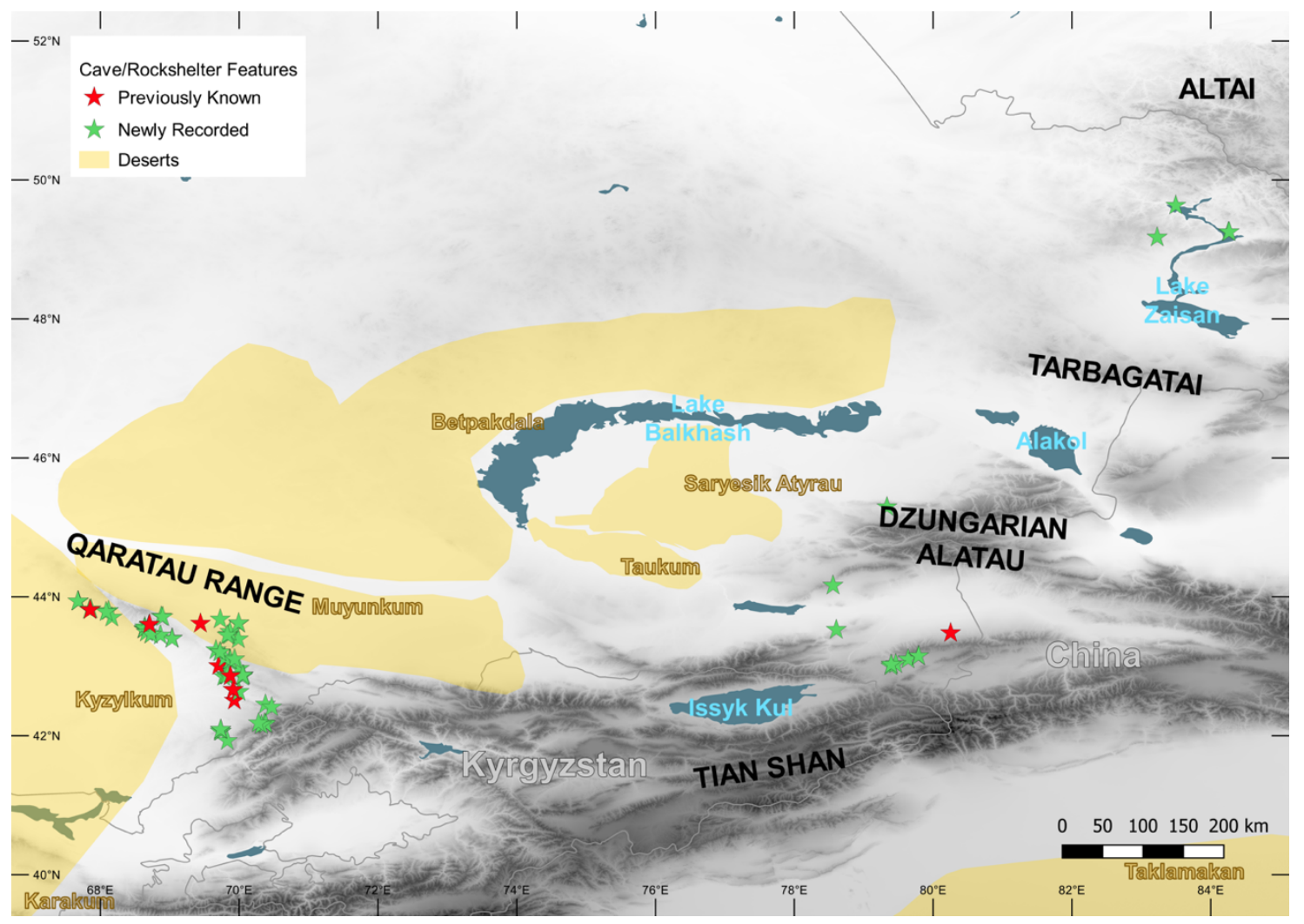

Figure 7. Caves surveyed by the PALAEOSILKROAD team from 2017-2019. A large number of the caves surveyed during this period have not previously been recorded, with a large proportion having been found in the Qaratau range. Including data from Global Administrative Areas (GADM) (Hijmans, 2012), Natural Earth, naturalearthdata.com, Shuttle Radar Topography Mission (SRTM) Version 4, (Jarvis et al., 2008)

Table 1. Tabulated karst and pseudokarst features with and without archaeology from survey seasons 2018-2019. *Based on surface/section finds and test-pit excavations in 10 features. ${ }^{* *}$ Based on stratigraphic observations (OSL and ${ }^{14} \mathrm{C}$ dating pending). NE: not excavated

\begin{tabular}{l|lccccc} 
Region & Context & Total & Sediment & $\begin{array}{c}\text { Archaeology } \\
\text { (Holocene) }\end{array}$ & $\begin{array}{c}\text { Archaeology } \\
\text { (Pleistocene)* }\end{array}$ & $\begin{array}{c}\text { Pleistocene? } \\
\text { (sterile)** }\end{array}$ \\
\hline Qaratau & caves & 67 & 23 & 14 & 2 & 4 \\
Tian Shan/Jungarian & shelters & 11 & 2 & $\mathrm{NE}$ & $\mathrm{NE}$ & $\mathrm{NE}$ \\
Alatau & caves & 11 & 2 & $\mathrm{NE}$ & $\mathrm{NE}$ & $\mathrm{NE}$ \\
& & & & & & \\
Altai (Kazakh) & shelters & 2 & 1 & 1 & 1 & 0 \\
\multirow{2}{*}{ Total } & caves & 0 & 0 & - & - & - \\
& shelters & 4 & 0 & - & - & - \\
\hline Grand total & caves & 78 & 25 & 14 & 2 & 4 \\
& shelters & 17 & 3 & 1 & 1 & 0 \\
\hline
\end{tabular}




\subsection{Spring sites}

As discussed in Section 2.3, in terms of their location, springs in our study region frequently form along tectonic fractures (faults, joints, fissures), in which the water reaches the surface by following a natural course of voids or weakness in the bedrock under hydrostatic pressure. Following the fault mapping work by Grützner et al (2019), we focused on the survey of tectonically activated springs located in various areas of the lli Basin and the Tarbagatai mountains. This relationship between tectonic faults, spring-fed rivers, and localities with surface lithics is particularly pronounced in a complex of sites on the northern side of the Tarbagatai mountains (see Figure 8). The springs and spring-fed rivers are associated with faults that run roughly east-west along the point in the landscape where the foothills meet the plains. Similar patterns were observed at the Tikenekti locality on the northern side of the Toraigyr mountains in the Trans-lli Alatau. A cluster of lithics was found at the Tikenekti locality, in the foothills surrounding a spring (Figure 9). The spring is notable for being one of only two on this side of the Toraigyr mountains, the other being located approximately $5.8 \mathrm{~km}$ eastwards of Tikenekti. Altyn Emel, on the southern side of the Jungarian Alatau, follows a similar pattern between sites, faults, and springs. However, 12 $\mathrm{km}$ to the east-south-east the site of Basshy is unique among our spring sites in being associated with a series of springs that disgorge into the nearby plains, apparently from associated faults that may meet in the area beneath the overlying quaternary deposits.
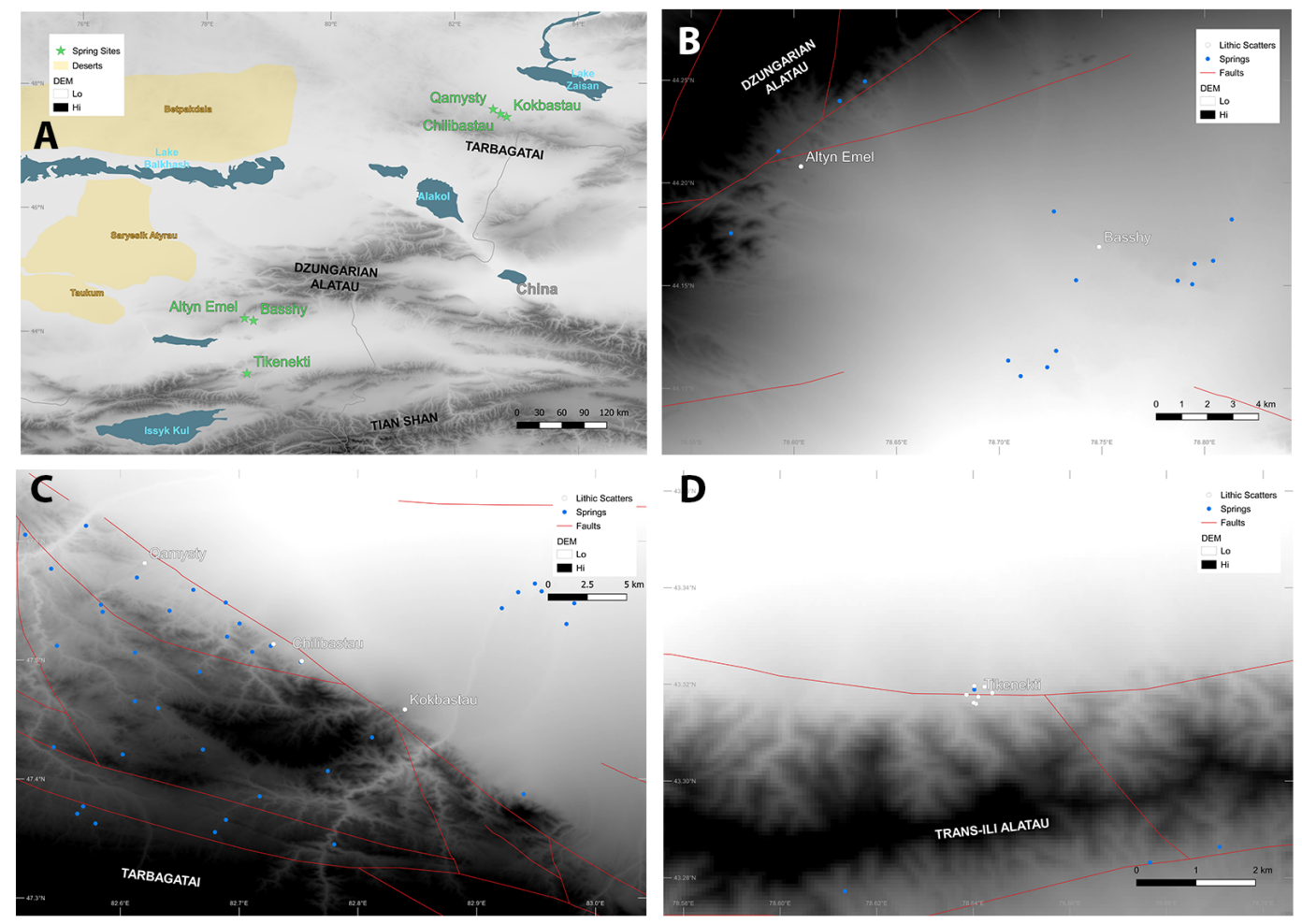

Figure 8 A) Overview of spring sites surveyed by the PALAEOSILKROAD team. This relationship between lithic scatters and springs has been observed north of the Tarbagatai range, and between the Dzungarian Alatau and the Tian Shan; B) spring sites of Altyn 
Emel and Basshy, on the south-eastern side of the Dzungarian Alatau, shown in relation to mapped springs and geological faults; C) spring sites along the north-eastern side of the Tarbagatai range, shown in relation to mapped springs and geological faults; D) spring sites in the locality of Tikenekti, surrounding a spring head. Shown in relation to other mapped springs and geological faults. Including data from Shuttle Radar Topography Mission (SRTM) Version 4, (Jarvis et al., 2008), Mineral Deposits Database and Thematic Maps of Central Asia (Seltmann et al., 2004).

The majority of the lithics found at the spring localities described above are non-diagnostic flakes and cores. Bullet cores typical of the Neolithic are sometimes found (e.g., at Kokbastau), although there is no reason to assume exclusively Holocene occupation. In fact, the diversity of the lithics found at these localities suggests instead that they were probably visited throughout the history of the springs themselves. Future excavations will show whether or not all the springs found on one fault share the same chronology and occupation histories.

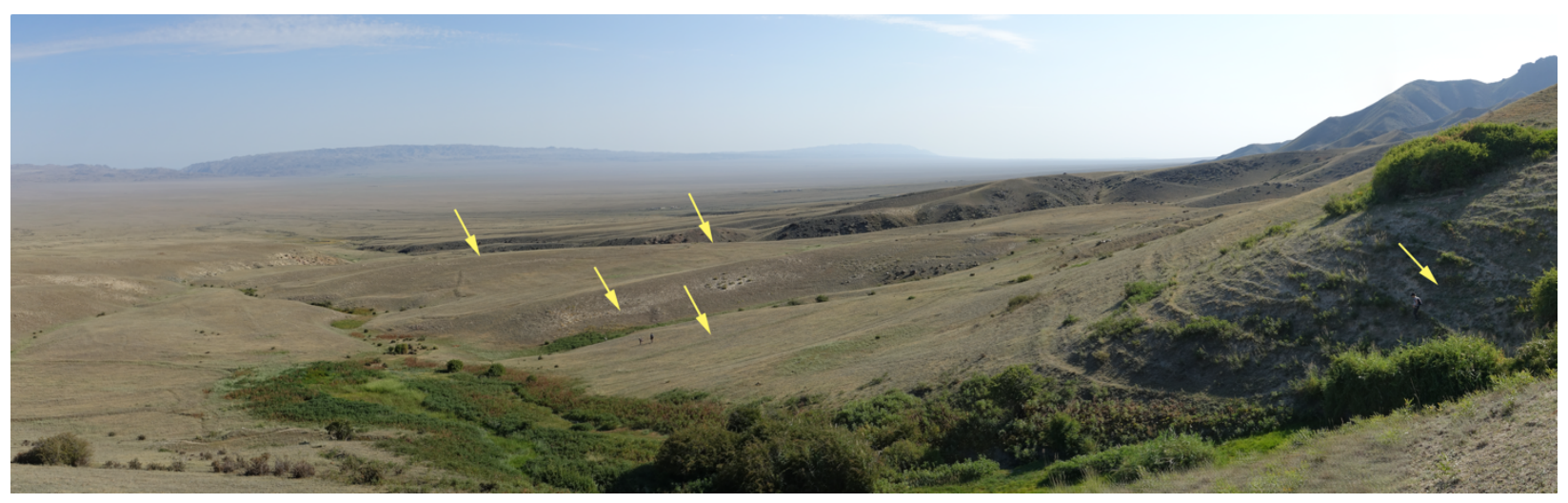

Figure 9 The Tikenekti locality with lithic finds on the surface. The arrows indicate spots where individual lithics were found. The main concentration is on both sides of the spring head.

\section{DISCUSSION: POSSIBLE BIASES IN THE ARCHAEOLOGICAL RECORD}

Kast/pseudokarst, loess, and spring settings could constitute important contexts for archaeological investigation in the Kazakh IAMC. However, their diachronic formation processes demand special attention, since they induce specific characteristics and possible biases in the archaeological record. To begin with, caves are the most obvious landscape features for preserving archaeological sites, so they are perfect targets for systematic surveys.

Moreover, they tend to have better organic preservation than open-air sites. However, as we saw in the previous section, efforts to locate Pleistocene archaeological sites in the Kazakh caves have so far had mixed results. We already stressed the importance of structural factors for cave evolution in Kazakhstan. Roof collapse events induced by structural instability bring contradicting implications for the preservation and discovery of archaeological sites in caves and rockshelters. On one hand, they produce an accumulation of tallus and big-sized rock fall debris that may seal occupation horizons as it has already been demonstrated for various well-known Paleolithic sites. Extensive collapse can also lead to the discovery of hitherto hidden caves (see Aqmeshit), while localized events can as well modify the morphology of the chambers and subsequently living space and human dwelling (see Tuttybulaq 1). The chimneys and fissures that often form as a consequence of roof collapse provide new pathways for sediment input into the cave. The impact of this mechanism for the development of thick cave sequences has been demonstrated in various case-studies inputting fine but also coarse sized surface materials underground (Jelinek et al., 1973; Goldberg et al., 2003). On the other hand, breaking through layers of rock fall 
presents significant logistical difficulties, especially in remote areas where manpower and technical support are hard to find.

Climate also plays a role in the accumulation of sediments in caves. In Kazakhstan, because of the semi-arid climate, slopes in areas of moderate to high relief are often erosional and mantled by the accumulation of unconsolidated rock debris ("scree"), in contrast with more humid climates, where slopes are mantled by a relatively thick soil cover (Frumkin et al., 2016). The increased solid fraction in relation to water in arid environments accumulates the sheets of coarse-sized debris at the foothills and valley sides forming talus (Karkanas and Goldberg, 2018). The amount and sheer size of material transported by the predominantly gravitational and free-fall flow processes described above is less likely to deposit fine sediment in cavities. Furthermore, it may lead to the erosion of caves and the masking of small shelters located at the base of slopes (Laville et al., 1980).

Based on our observations, the most common surface material that enters karst and pseudokarst features in Kazakhstan is aeolian loess. Topographic attributes including location, aspect, position, and slope morphology, as well as atmospheric circulation patterns like dust dynamics and wind direction greatly impact the deposition of this wind-blown sediment (Goldberg and Sherwood, 2006; lovita et al., 2012). Therefore, we expect that local variations in loess cover (currently known on a very coarse scale, Figure 6) would determine the presence or absence of loess in natural cavities. Consequently, cavities lacking loess infill, especially in the case of limited autochthonous deposition, have a low probability of archaeological preservation.

In the case of pseudokarst features, on the other hand, the type of parent lithology seems to be the primary factor affecting the probability of sediment accumulation in the sheltered area. Based on our field observations, pseudokarst developed in sandstone constitutes the most promising setting for autochthonous geogenic sedimentation, which can ultimately lead to burial and preservation of archaeological remains.

As discussed above, loess deposits also constitute propitious archives for the preservation of archaeological sites. However, there are significant limitations that must be discussed. First, the thickness of loess cover suggests that many of the older parts of the landscape are irrevocably lost under massive amounts of sediment that can never be excavated completely. This presents a strong bias against older sites and may be the reason why no Middle Paleolithic sites have been so far discovered in loess in Kazakhstan. This brings us to the second point, which is visibility and landscape preference (e.g., Tryon, 2010). Loess sites are easy to identify in road cuttings or if preserved in river bank cliff deposits, because the whole sequence is visible and lithics, bones, and charcoal are often recognized during survey. However, not all such cuts and erosional features hide Paleolithic sites, and many Paleolithic sites undoubtedly lie completely undisturbed in unavailable landscape positions. For this reason, loess sites, like caves, present a very biased picture of landscape preferences of ancient humans. Likewise, they may distort arguments that rely on comparing distributions of sites by time period, as the older time periods will be underrepresented.

Loess cover in Kazakhstan is different from that of other regions in arid central Asia (see Figure 6), especially that encountered in China (Fitzsimmons et al., 2018; Sprafke et al., 2018). Unlike on the Chinese loess plateau (and also in Tajikistan), the thickness of the strata is influenced by the underlying topography (Sprafke et al., 2018) so that it is difficult to target a particular time period by field-walking near predetermined strata (e.g., see paleosols, see Zhu et al., 2018). Moreover, the problem of loess thickness affects the visibility of other traps that are relevant to Paleolithic archaeology, such as caves and rockshelters, which may be completely obscured by thick loess accumulations (see also lovita et al., 2014 for a discussion of similar problems in southeastern Europe).

Coming to our final possible archive of past human activity in the IAMC, springs, we note that they can be found in each of our four study regions, allowing for possible comparisons and systematic targeting. However, so far we have identified several kinds of springs by discharge and origin types (Springer and Stevens, 2009), but we are unsure of the timing of their inception. It is possible that some of them are recently formed (in the Holocene) as a result of water table changes, others may be cutting through channels of extinct small rivers (that may themselves have been glacier-fed). For this reason, the lithics found on the surface in and nearby springs could be telling a 
variety of stories, some related directly to springs as a habitation site chosen by hominins, and others as agents of exposure of archaeological remains.

\section{FUTURE WORK}

4

Understanding the processes that affect the preservation and visibility of Pleistocene archaeological record in IAMC is a challenging task and requires intensive fieldwork. In this paper we demonstrated not only that karst/pseudokarst, loess, and spring settings are prominent contexts for archaeological investigation in IAMC, but that they are each characterized by different attributes that impact their archaeological potential. A deeper understanding of the record formation requires analyses at both the site and landscape scale.

First of all, investigating further the sedimentary sequences recorded in some rockshelters and caves will provide an in-depth study of cave development and infilling. Ongoing dating and paleoenvironmental analysis of cave sediments will be integrated in paleoclimatic reconstructions, possibly correlated with the already well-established loess record. Ultimately, understanding the formation processes of karst and pseudokarst based on sedimentary and geomorphological criteria could evaluate the potential of those sites for human occupation through time. Comparing cave and loess sequences remains a distant goal for now, but one that we believe is achievable in the medium- to long-term.

In this context, it is important to explore further the relationship between faulting and cave development for specific areas of Kazakhstan. Should such a positive correlation be established, faults could provide a relative chronological marker for the formation of the caves and their structural evolution. Secondly, it would suggest the need for changing survey tactics for the discovery of new caves, putting focus on areas where mapped faults intersect the landscape. As it can be demonstrated in the area of Lesser Boraldai, faults are frequently perpendicular to river courses. Surveying along the course of rivers is a good survey strategy since rivers dissect the landscape and provide easy access to mountain passages and inter-mountainous valleys. Moreover, they may have formed cavities by eroding the bedrock and they would have offered access to fresh water to hominins and animals. Given the logistical difficulties involved in surveying deep canyons (low visibility from the bottom, difficult climbing), following fault lines and uplifted uplands could provide an auxiliary survey solution.

In order to increase the probability of finding Paleolithic occupation in proximity to springs, it will be necessary to focus on areas that promote the formation of more stable spring channels. Perennial springs, which sustained freshwater discharge during the climatic fluctuations of the Late Pleistocene should have been significant landmarks for hominins. The more frequent visits to these localities, as opposed to those with more ephemeral springs, should therefore translate to a higher accumulation of cultural material. According to Cartwright and Johnson (2018), the stability of spring discharge is determined by type of recharge, flow-path length, groundwater volume and residence time. They specifically note that large-volume springs with relatively stable discharge are commonly associated with extensive, high-primary-permeability geologic units or with geologic structure and faulting that provide secondary permeability in the aquifer. In their discussion, long term springs are often characterized by extensive underground flow paths and long-term mean residence times that can span decades or even centuries.

Last but not least, improving our rate of success in discovering loess sites will likely depend upon intensive foot surveys of specific valleys, to obtain more data on the relationship between landscape position and the probability of site discovery.

\section{CONCLUSIONS}


A combination of paleoanthropological, geographic, and paleoclimatic factors strongly suggests that a corridor roughly similar to what we now call the Silk Road likely existed during the Pleistocene. Whether hominins used this corridor for dispersal throughout the last glacial cycle or not remains still to be evaluated through extensive archaeological fieldwork. In this article, we have attempted to evaluate the chances of that fieldwork yielding the results we need for modeling hominin behavior. From our field observations, it is clear that the archaeological record has some in-built biases, which will be difficult to overcome even by systematic survey. First, the main targetable archives are geographically not equally distributed. Karstic features, our best hope for good organic preservation and longer sequences that could be used to evaluate long-term human occupation, are present in two clusters more than $1000 \mathrm{~km}$ apart, (in the Qaratau and the Jungarian/Trans-Ili Alatau). Although piedmont loess covers much of the area in between these two clusters, it remains difficult to find sites because of the limited number of exposures, which mostly occur in the form of road cuts or river banks. Moreover, the sites that have been found so far in loess have been only Upper Paleolithic in age, thus missing the earlier part of the record of interest. Given that typologically Middle Paleolithic lithics are known from deflated contexts elsewhere in the country, we expect stratified Middle Paleolithic sites to be there, but probably deeply buried. This could be a reason for the pattern we have previously reported in our review (Fitzsimmons et al., 2017, Fig. 8), where cave and rockshelter settings in Central Asia preserve older occupations. Finally, we have found ample evidence for Stone Age occupation nearby springs and documented patterns of association between springs and fault lines, which we plan to use to plan future surveys.

In conclusion, the search for a Paleolithic Silk Road through Kazakhstan is just beginning. Although we remain optimistic about the region's archaeological potential, we would like to caution, at least for now, against grand theories of cultural diffusion or actual dispersals often illustrated by 'drawing arrows on maps'.

\section{ACKNOWLEDGEMENTS}

We would like to thank Andrei Krivoshapkin, Arina Khatsenovich, Evgeny Rybin, Nicolas Zwyns, and John Olsen for inviting us to contribute this paper, which is based on a presentation at the UISPP 2018 symposium on the Prehistory of Central Asia. We thank Saman Heydari-Guran and Diego E. Angelucci for their helpful reviews of this paper's first draft. In Kazakhstan, we thank Dean Mendigul Nogaibaeva and Prof. Gani Omarov (Faculty of History, Ethnology, and Archaeology, Kazakh National University) for their unwavering support of our project. We would like to acknowledge Dr. Gani Iskakov (Turkestan Museum), now sadly deceased, who joined us in our South Kazakhstan field season in 2018. We would also like to thank our many student volunteers, without which this work would have been impossible. Finally, we would like to thank our field support staff and the local people who helped us find so many caves. A. Varis would like to thank G. Lazaridis (School of Geology, Aristotle University of Thessaloniki) for his comments on cave development and faulting. The PALAEOSILKROAD project conducted all field research under license No. 15008746 (12.05.2015) of the National Museum of the Republic of Kazakhstan based on the collaboration protocol between the Eberhard-Karls University of Tübingen and the National Museum. This project has received funding from the European Research Council (ERC) under the European Union's Horizon 2020 research and innovation programme (grant agreement $n^{\circ} 714842$; PALAEOSILKROAD project).

\section{BIBLIOGRAPHY}


Alpysbaev, H.A., 1961. Otkrytie pamyatnikov drevnego i pozdnego paleolita Yuzhnogo Kazakhstana [Discovering of early and late Paleolithic sites in South Kazakhstan] 1, 128-138.

Alpysbaev, H.A., 1970. Nekotorye voprosy izucheniya pamyatnikov kamennogo veka v Kazakhstane [Some questions on the study of the Stone Age in Kazakhstan]. Po sledam drevnikh kul'tur Kazakhstana, Alma-Ata 227-240.

Alpysbaev, H.A., 1979. Pamyatniki nizhnego paleolita yuzhnogo Kazakhstana [Lower Paleolithic sites of Southern Kazakhstan]. Almaty.

Andrews, J.E., 2006. Palaeoclimatic records from stable isotopes in riverine tufas: Synthesis and review. Earth Science Reviews 75, 85-104. doi:10.1016/j.earscirev.2005.08.002

Anoikin, A.A., Taimagambetov, Z.K., Uliyanov, V. A., Kharevich, V.M., Shalagina, A.V., Pavlenok, G.D., Markovskii, G.I., Gladyshev, S.A., Chekha, A.M., Iskakov, G.T., Vasiliev, S.K., 2017. Issledovanie industrii nachal'nyh ehtapov verhnego paleolita na stoyanke Ushbulak-1 (Vostochnyi Kazahstan) v 2017 godu. [Studies of the Initial Upper Paleolithic Industry at the Ushbulak-1 Site (Eastern Kazakhstan) in 2017]. Problems of Archaeology, Ethnography, Anthropology of Siberia and Neighboring Territories 23, 1925.

Artyukhova, O.A., 1990. Must'e Kazahstana [The Mousterian of Kazakhstan]. In: Hronostratigrafiya Paleolita Severnoy, Centralnoy, Vostochnoy Azii i Ameriki [Chronostratigraphy of the Paleolithic of Northern, Central, and Eastern Asia and America]. Novosibirsk, pp. 35-39.

Artyukhova, O.A., Mamirov, T.B., 2014. Kamennyi vek Saryarki: evolutsiya kultur ot drevepaleoliticheskikh okhotnikov do pervykh metallurgov v svete noveishikh issledovanyi [Stone Age of Saryarka: the evolution of cultures from ancient Paleolithic hunters to the first metallurgists in the light of the latest research]. Almaty.

Audra, P., Palmer, A.N., 2011. The pattern of caves: controls of epigenic speleogenesis. Géomorphologie : relief, processus, environnement 17, 359-378. doi:10.4000/geomorphologie.9571

Barboni, D., Ashley, G., Bourel, B., Arráiz, H., Mazur, J.-C., 2019. Springs, palm groves, and the record of early hominins in Africa. Review of Palaeobotany and Palynology 266, $23-41$. doi:10.1016/j.revpalbo.2019.03.004

Baytanaev, B.A., Goryachev, A.A., Sarayev, V.V., Shayakhmetov, A.H., 2017. Arkheologicheskie issledovaniya pamyatnikov rannego zheleznogo veka v predgor'yakh Karatau i u severnykh sklonov khrebta Karzhantau [Archaeological researches of the Early Iron Age monuments in the foothills of Karatau and northern slopes of Karzhantau ridge]. Proceedings of the National Academy of Sciences of the Republic of Kazakhstan, Social and Human Sciences 1, 143-159.

Baytanaev, B.A., Goryachev, A.A., Egorova, T.A., Ergeshbaev, A.A., Baytanaeva, A.B., Baytanaev, E.B., 2018. Arkheologicheskie issledovaniya v peschere Tuttybulaq-1 v 2018 g. [Archaeological research in Tuttybulaq1 cave in 2018]. Arkheologiya Kazakhstana 1-2.

Beeton, T.A., Glantz, M.M., Trainer, A.K., Temirbekov, S.S., Reich, R.M., 2014. The fundamental hominin niche in late Pleistocene Central Asia: a preliminary refugium model. Journal of Biogeography 41, 95-110.

Benson, R.C., Yuhr, L.B., 2016. Site Characterization in Karst and Pseudokarst Terraines: Practical Strategies and Technology for Practicing Engineers, Hydrologists and Geologists. Springer Netherlands. doi:10.1007/97894-017-9924-9

Bíl, M., Kubecek, J., 2012. Piping in loess-like and loess-derived soils: Case study of Halenkovice site, Czech Republic. Annales Societatis Geologorum Poloniae 82, 45-50.

Blomdin, R., Stroeven, A.P., Harbor, J.M., Lifton, N.A., Heyman, J., Gribenski, N., Petrakov, D.A., Caffee, M.W., Ivanov, M.N., Hättestrand, C., Rogozhina, I., Usubaliev, R., 2016. Evaluating the timing of former glacier expansions in the Tian Shan: A key step towards robust spatial correlations. Quaternary Science Reviews 153, 78-96. doi:10.1016/j.quascirev.2016.07.029

Boivin, N., Fuller, D.Q., Dennell, R., Allaby, R., Petraglia, M.D., 2013. Human dispersal across diverse environments of Asia during the Upper Pleistocene. Quaternary International, The Middle Palaeolithic in the Desert 300, 32-47. doi:10.1016/j.quaint.2013.01.008

Cartwright, J., Johnson, H.M., 2018. Springs as hydrologic refugia in a changing climate? A remote-sensing approach. Ecosphere 9, e02155. doi:10.1002/ecs2.2155 
Chekha, A.M., 2017. Istoriya issledovaniya kamennogo veka Kazahstana [The history of Paleolithic research in Kazakhstan]. Vestnik NGU. Seriya: Istoriya, filologiya 16, 15-25.

Chen, F., Welker, F., Shen, C.-C., Bailey, S.E., Bergmann, I., Davis, S., Xia, H., Wang, H., Fischer, R., Freidline, S.E., Yu, T.-L., Skinner, M.M., Stelzer, S., Dong, G., Fu, Q., Dong, G., Wang, J., Zhang, D., Hublin, J.-J., 2019. A late Middle Pleistocene Denisovan mandible from the Tibetan Plateau. Nature 569, 409-412. doi:10.1038/s41586-019-1139-x

Cuthbert, M.O., Gleeson, T., Reynolds, S.C., Bennett, M.R., Newton, A.C., McCormack, C.J., Ashley, G.M., 2017. Modelling the role of groundwater hydro-refugia in East African hominin evolution and dispersal. Nature Communications 8, 1-11. doi:10.1038/ncomms15696

Dennell, R., 2017. Human Colonization of Asia in the Late Pleistocene: The History of an Invasive Species. Current Anthropology 58, S383-S396. doi:10.1086/694174

Derevianko, A.P., Petrin, V.T., Taimagambetov, Z.K., Zenin, A.N., Gladyshev, S.A., 1999. Paleoliticheskie kompleksy poverhnostnogo zaleganiya Mugodzharskih gor [Surface Paleolithic complexes of the Mugodzharian mountains]. Problemy arxeologii, etnografii, antropologii Sibiri i sopredel'nyh teritoriy 5, 5055.

Derevianko, A.P., Petrin, V.T., Taimagambetov, Ž.K., Isabekov, Z.K., Rybalko, R.G., Otte, M., 2000. Lower Paleolithic microindustrial travertine complexes of Southern Kazakhstan (Раннепалеолитические микроиндустриальные комплексы в травертинах южного Казахстана), Издательство Института археологии и этнографии СО РАН. Russian Academy of Sciences, Siberian Branch, Novosibirsk.

Derevianko, A.P., Petrin, V.T., Nikolaev, S.A., Taimagambetov, Z.K., Tserendagva, Y., 2002. Rannepaleoliticheskiy kompleks Kyzyltau 1 v Yuzhnom Kazahstane [The Lower Paleolithic complex Kyzyltau 1 in South Kazakhstan]. Problemy kamennogo veka Sredney i Central'noy Azii 74-91.

Derevianko, A.P., Xing, G., Olsen, J.W., Rybin, E.P., 2012. The Paleolithic of Dzungaria (Xinjiang, Northwest China) Based on Materials from the Luotuoshi Site. Archaeology, Ethnology and Anthropology of Eurasia 40, 2 18. doi:10.1016/j.aeae.2013.04.002

Derevianko et al., 2017. Arkheologicheskie raboty v Shiliktinskoi doline na vostoke Kazahstana v 2017 godu [Archaeological works in Shiliktivalley in the east of Kazakhstan in 2017]. Problems of Archaeology, Ethnography, Anthropology of Siberia and Neighboring Territories.

Devièse, T., Massilani, D., Yi, S., Comeskey, D., Nagel, S., Nickel, B., Ribechini, E., Lee, J., Tseveendorj, D., Gunchinsuren, B., Meyer, M., Pääbo, S., Higham, T., 2019. Compound-specific radiocarbon dating and mitochondrial DNA analysis of the Pleistocene hominin from Salkhit Mongolia. Nature Communications 10, 1-7. doi:10.1038/s41467-018-08018-8

Dodonov, A.E., 2007. LOESS RECORDS | Central Asia. In: Encyclopedia of Quaternary Science. Elsevier, pp. 14181429. doi:10.1016/B0-44-452747-8/00161-7

Feng, Z.D., Ran, M., Yang, Q.L., Zhai, X.W., Wang, W., Zhang, X.S., Huang, C.Q., 2011. Stratigraphies and chronologies of late Quaternary loess-paleosol sequences in the core area of the central Asian arid zone. Quaternary International 240, 156-166. doi:10.1016/j.quaint.2010.10.019

Fitzsimmons, K.E., Iovita, R., Sprafke, T., Glantz, M., Talamo, S., Horton, K., Beeton, T., Alipova, S., Bekseitov, G., Ospanov, Y., Deom, J.-M., Sala, R., Taimagambetov, Z., 2017. A chronological framework connecting the early Upper Palaeolithic across the Central Asian piedmont. Journal of Human Evolution 113, 107-126. doi:10.1016/j.jhevol.2017.07.006

Fitzsimmons, K.E., Sprafke, T., Zielhofer, C., Günter, C., Deom, J.-M., Sala, R., Iovita, R., 2018. Loess accumulation in the Tian Shan piedmont: Implications for palaeoenvironmental change in arid Central Asia. Quaternary International 30-43. doi:10.1016/j.quaint.2016.07.041

Ford, D., Williams, P.W., 2007. Karst hydrogeology and geomorphology. John Wiley \& Sons, Chichester, England.

Frachetti, M.D., 2012. Multiregional Emergence of Mobile Pastoralism and Nonuniform Institutional Complexity across Eurasia. Current Anthropology 53, 2-38. doi:10.1086/663692

Frachetti, M.D., Smith, C.E., Traub, C.M., Williams, T., 2017. Nomadic ecology shaped the highland geography of Asia's Silk Roads. Nature 543, 193-198. doi:10.1038/nature21696

Frumkin, A., Fischhendler, I., 2005. Morphometry and distribution of isolated caves as a guide for phreatic and confined paleohydrological conditions. Geomorphology 67, 457-471. doi:10.1016/j.geomorph.2004.11.009 
Frumkin, A., Langford, B., Marder, O., Ullman, M., 2016. Paleolithic caves and hillslope processes in south-western Samaria, Israel: Environmental and archaeological implications. Quaternary International 398, 246-258. doi:10.1016/j.quaint.2015.05.064

Fu, Q., Li, H., Moorjani, P., Jay, F., Slepchenko, S.M., Bondarev, A.A., Johnson, P.L., Aximu-Petri, A., Prüfer, K., Filippo, C. de, Meyer, M., Zwyns, N., Salazar-García, D.C., Kuzmin, Y.V., Keates, S.G., Kosintsev, P.A., Razhev, D.I., Richards, M.P., Peristov, N.V., Lachmann, M., Douka, K., Higham, T.F.G., Slatkin, M., Hublin, J.-J., Reich, D., Kelso, J., Viola, T.B., Pääbo, S., 2014. Genome sequence of a 45,000-year-old modern human from western Siberia. Nature 514, 445-449.

Gillieson, D., 1996. Caves: Processes, Development and Management. Blackwell Publishing Ltd., Oxford, UK. doi: $10.1002 / 9781444313680$

Glantz, M., Van Arsdale, A., Temirbekov, S., 2015. How to survive the glacial apocalypse: bugging out in late Pleistocene Central Asia. In: American Journal of Physical Anthropology. p. 145.

Gokcumen, O., 2019. Archaic hominin introgression into modern human genomes. American Journal of Physical Anthropology 1-19. doi:10.1002/ajpa.23951

Goldberg, P., Sherwood, S.C., 2006. Deciphering human prehistory through the geoarcheological study of cave sediments. Evolutionary Anthropology: Issues, News, and Reviews 15, 20-36. doi:10.1002/evan.20094

Goldberg, P., Schiegl, S., Meligne, K., Dayton, C., Conard, N., 2003. Micromorphology and site formation at Hohle Fels Cave, Swabian Jura, Germany. Eiszeitalter und Gegenwart 53, 1-25.

Grigoriev, F.P., Volkov, B.A., 1998. Novye materialy o peshchere Ushbas [New materials from Ushbas Cave]. Vestnik Universiteta Yassavi 1, 68-75.

Grimes, K., 1975. Pseudokarst, definition and types. In: Graham, A.W. (Ed.), Tenth Biennial Conference. Australian Speleological Federation, Brisbane, pp. 6-10.

Grützner, C., Campbell, G., Walker, R.T., Jackson, J., Mackenzie, D., Abdrakhmatov, K., Mukambayev, A., 2019. Shortening Accommodated by Thrust and Strike-Slip Faults in the Ili Basin, Northern Tien Shan. Tectonics 38, 2255-2274. doi:10.1029/2018TC005459

Halliday, W., 2007. Pseudokarst in the 21(st) century. Journal of Cave and Karst Studies 69, 103-113.

Heydari, S., 2007. The impact of geology and geomorphology on cave and rockshelter archaeological site formation, preservation, and distribution in the Zagros mountains of Iran. Geoarchaeology 22, 653-669. doi:10.1002/gea.20179

Hijmans, R., 2012. GADM database of global administrative areas (version 2.0).

Holler, C., 2019. Chapter 101 - Pseudokarst. In: White, W.B., Culver, D.C., Pipan, T. (Eds.), Encyclopedia of Caves (Third Edition). Academic Press, pp. 836-849. doi:10.1016/B978-0-12-814124-3.00101-1

Hu, Y., Marwick, B., Zhang, J.-F., Rui, X., Hou, Y.-M., Yue, J.-P., Chen, W.-R., Huang, W.-W., Li, B., 2019. Late Middle Pleistocene Levallois stone-tool technology in southwest China. Nature 565, 82-85. doi:10.1038/s41586-018-0710-1

Huerta-Sánchez, E., Jin, X., Asan, Bianba, Z., Peter, B.M., Vinckenbosch, N., Liang, Y., Yi, X., He, M., Somel, M., Ni, P., Wang, B., Ou, X., Huasang, Luosang, J., Cuo, Z.X.P., Li, K., Gao, G., Yin, Y., Wang, W., Zhang, X., Xu, X., Yang, H., Li, Y., Wang, J., Wang, J., Nielsen, R., 2014. Altitude adaptation in Tibetans caused by introgression of Denisovan-like DNA. Nature 512, 194-197. doi:10.1038/nature13408

Iovita, R., Fitzsimmons, K.E., Doboș, A., Hambach, U., Hilgers, A., Zander, A., 2012. Dealul Guran: evidence for Lower Palaeolithic (MIS 11) occupation of the Lower Danube loess steppe. Antiquity 86, 973-989. doi:10.1017/S0003598X00048195

Iovita, R., Doboş, A., Fitzsimmons, K.E., Probst, M., Hambach, U., Robu, M., Vlaicu, M., Petculescu, A., 2014. Geoarchaeological prospection in the loess steppe: Preliminary results from the Lower Danube Survey for Paleolithic Sites (LoDanS). Quaternary International 351, 98-114. doi:10.1016/j.quaint.2013.05.018

James, HannahV.A., Petraglia, MichaelD., 2005. Modern Human Origins and the Evolution of Behavior in the Later Pleistocene Record of South Asia. Current Anthropology 46, S3-S27. doi:10.1086/444365

Jarvis, A., Reuter, H.I., Nelson, A., Guevara, E., 2008. Hole-filled SRTM for the globe Version 4.

Jelinek, A.J., Farrand, W.R., Haas, G., Horowitz, A., Goldberg, P., 1973. New excavations at the Tabun cave, Mount Carmel, Israel, 1967-1972 : A preliminary report. Paléorient 1, 151-183. doi:10.3406/paleo.1973.4163

Kajdas, B., Michalik, M.J., Migoń, P., 2017. Mechanisms of granite alteration into grus, Karkonosze granite, SW Poland. CATENA 150, 230-245. doi:10.1016/j.catena.2016.11.026 
Karkanas, P., Goldberg, P., 2018. Reconstructing Archaeological Sites: Understanding the Geoarchaeological Matrix. Wiley-Blackwell, Hoboken, NJ,USA.

King, G., Bailey, G., 2006. Tectonics and human evolution. Antiquity 80, 265-286. doi:10.1017/S0003598X00093613

Klapchuk, M., 1971. Arheologicheskie nahodki u hrebta Zhaman-Aibat (Kazahstan) [Archaeological finds in the Zhaman-Aibat range (Kazakhstan)]. Materialy i issledovaniya po arheologii SSSR (dalee MIA) 233-239.

Koppes, M., Gillespie, A.R., Burke, R.M., Thompson, S.C., Stone, J., 2008. Late Quaternary glaciation in the Kyrgyz Tien Shan. Quaternary Science Reviews 27, 846-866. doi:10.1016/j.quascirev.2008.01.009

Kresic, N., Stevanović, Z., 2010. Groundwater Hydrology of Springs. doi:10.1016/C2009-0-19145-6

Kuzmin, Y.V., Kosintsev, P.A., Razhev, D.I., Hodgins, G.W.L., 2009. The oldest directly-dated human remains in Siberia: AMS 14C age of talus bone from the Baigara locality, West Siberian Plain. Journal of Human Evolution 57, 91-95. doi:10.1016/j.jhevol.2009.04.003

Laville, H., Rigaud, J.P., Sackett, J., 1980. Rock shelters of the Perigord: Geological Stratigraphy and Archaeological Succession. New York, N.Y. : Academic Press.

Lehmkuhl, F., Klinge, M., Stauch, G., 2011. The extent and timing of Late Pleistocene glaciations in the Altai and neighbouring mountain systems. In: Quaternary Glaciations - Extent and Chronology. A Closer Look, Developments in Quaternary Science. Elsevier, Amsterdam, pp. 967-980.

Lehner, B., Verdin, K., Jarvis, A., 2006. HydroSHEDS technical documentation, version 1.0. World Wildlife Fund US, Washington, DC 1-27.

Li, F., Kuhn, S.L., Chen, F., Wang, Y., Southon, J., Peng, F., Shan, M., Wang, C., Ge, J., Wang, X., Yun, T., Gao, X., 2018a. The easternmost Middle Paleolithic (Mousterian) from Jinsitai Cave, North China. Journal of Human Evolution 114, 76-84. doi:10.1016/j.jhevol.2017.10.004

Li, F., Vanwezer, N., Boivin, N., Gao, X., Ott, F., Petraglia, M., Roberts, P., 2019. Heading north: Late Pleistocene environments and human dispersals in central and eastern Asia. PLOS ONE 14, e0216433. doi:10.1371/journal.pone.0216433

Li, F., Li, Y., Gao, X., Kuhn, S.L., Boëda, E., Olsen, J.W., n.d. A refutation of reported Levallois technology from Guanyindong Cave in South China. National Science Review. doi:10.1093/nsr/nwz115

Li, Y., Hou, Y., Boëda, E., 2009. Mode of débitage and technical cognition of hominids at the Guanyindong site. Chinese Science Bulletin 54, 3864-3871. doi:10.1007/s11434-009-0612-6

Li, Y., Mao, J., Xiang, X., Mo, P., 2018b. Factors influencing development of cracking-sliding failures of loess across the eastern Huangtu Plateau of China. Natural Hazards and Earth System Sciences 18, 1223-1231. doi:10.5194/nhess-18-1223-2018

Liu, W., Martinón-Torres, M., Cai, Y., Xing, S., Tong, H., Pei, S., Sier, M.J., Wu, X., Edwards, R.L., Cheng, H., Li, Y., Yang, X., Castro, J.M.B. de, Wu, X., 2015. The earliest unequivocally modern humans in southern China. Nature 526, 696-699. doi:10.1038/nature15696

Lukić, T., Marković, S.B., Stevens, T., Vasiljević, D.A., Machalett, B., Milojković, N., Basarin, B., Obreht, I., 2009. The Loess "Cave" Near the Village of Surduk - an Unusual Pseudokarst Landform in the Loess of Vojvodina, Serbia. Acta Carsologica 38, 227-235. doi:10.3986/ac.v38i2-3.124

Machalett, B., Oches, E.A., Frechen, M., Zöller, L., Hambach, U., Mavlyanova, N.G., Marković, S.B., Endlicher, W., 2008. Aeolian dust dynamics in central Asia during the Pleistocene: Driven by the long-term migration, seasonality, and permanency of the Asiatic polar front. Geochemistry, Geophysics, Geosystems 9, Q08Q09. doi:10.1029/2007GC001938

Märker, M., Heydari-Guran, S., 2009. Application of datamining technologies to predict Paleolithic site locations in the Zagros Mountains of Iran. In: Proceedings of CAA.

Martinón-Torres, M., Wu, X., Bermúdez de Castro, J.M., Xing, S., Liu, W., 2017. Homo sapiens in the Eastern Asian Late Pleistocene. Current Anthropology 58, S434-S448. doi:10.1086/694449

Medoev, A.G., 1964. Kamennyi vek Sary-Arka v svete noveishikh issledovanyi [Stone Age of Sary-Arka in the light of the latest research]. Seriya obschest.nauk 6, 55-66.

Medoev, A.G., 1982. Geohronologiya paleolita Kazahstana. Nauka, Alma Ata.

Mors, R.A., Astini, R.A., Gomez, F.J., 2019. Coexisting active travertines and tufas in the southeastern border of the Puna plateau. Sedimentary Geology 389, 200-217. doi:10.1016/j.sedgeo.2019.06.009 
Nasab, H.V., Clark, G.A., Torkamandi, S., 2013. Late Pleistocene dispersal corridors across the Iranian Plateau: A case study from Mirak, a Middle Paleolithic site on the northern edge of the Iranian Central desert (Dasht-e Kavir). Quaternary International 300, 267-281. doi:10.1016/j.quaint.2012.11.028

Owen, L.A., Dortch, J.M., 2014. Nature and timing of Quaternary glaciation in the Himalayan-Tibetan orogen. Quaternary Science Reviews 88, 14-54. doi:10.1016/j.quascirev.2013.11.016

Ozherelyev, D.V., 2007. Pozdnepaleoliticheskie pamyatniki Kazakhstana [Late Paleolithic sites of Kazakhstan]. AlFarabi Kazakh National University, Almaty.

Ozherelyev, D.V., Dzhasybaev, E.A., Mamirov, T.B., 2019. Pervye dannye o stratigrafii i kul'turnoĭ atribucii mnogoslŏnoĭ stojanki verhnego paleolita Rahat (Jugo-Vostochnyı̌ Kazahstan) [First data on the stratigraphy and cultural attribution of the Upper Paleolithic site of Rakhat (Southeast Kazakhstan)]. Kratkie soobshcheniya instituta arkheologii RAN Moskva 57-70.

Palmer, A.N., 1991. Origin and morphology of limestone caves. GSA Bulletin 103, 1-21. doi:10.1130/00167606(1991)103<0001:OAMOLC >2.3.CO;2

Palmer, A.N., 2002. Speleogenesis in carbonate rocks. In: Gabrovsek, F. (Ed.), Evolution of Karst: From Prekarst to Cessation, Postojna-Ljubljana. Zaloza-ZRC, pp. 43-60.

Pavuza, R., Plan, L., 2013. Loess caves of Austria - A preview. Cadernos do Laboratorio Xeoloxico de Laxe 37, 6572.

Reyes-Centeno, H., Ghirotto, S., Detroit, F., Grimaud-Herve, D., Barbujani, G., Harvati, K., 2014. Genomic and cranial phenotype data support multiple modern human dispersals from Africa and a southern route into Asia. Proceedings of the National Academy of Sciences of the United States of America 111, 7248-7253. doi:10.1073/pnas.1323666111

Rybin, E.P., 2014. Tools, beads, and migrations: Specific cultural traits in the Initial Upper Paleolithic of Southern Siberia and Central Asia. Quaternary International, Recent advances in studies of the late Pleistocene and Palaeolithic of Northeast Asia 347, 39-52. doi:10.1016/j.quaint.2014.04.031

Self, C., Hill, C., 2003. How speleothems grow: An introduction to the ontogeny of cave minerals. Journal of Cave and Karst Studies 65, 135-151.

Seltmann, R., Shatov, V., Yakubchuk, A., 2004. Mineral deposits database and thematic maps of Central Asia, scale 1.5 million: ArcView 3.2 and MapInfo 6.0 (7.0) GIS Packages, Explanatory Notes, CERCAMS. Natural History Museum, London, UK 117.

Shakalov, A.A., 2010. Poisk peshcher v rayonakh yugo-vostochnogo Kazakhstana [Research and prospecting for caves in South East Kazakhstan region]. In: Speleologiya i Spelestologiya: Razvitie i Vzaimodeystvie Nauk. Presented at the Materialy mezhdunarodnoy nauchno-prakticheskoy konferentsii, Naberezhnye Chelny, pp. $77-78$.

Smieja, A., Smieja-Król, B., 2007. Springs with active calcium carbonate precipitation in the Polish part of the Tatra Mountains. In: Tyc, A., Stefaniak, K. (Eds.), Karst and Cryokarst. Faculty of Earth Science, University of Silesia, Sosnowiee-Wroclaw, pp. 219-226.

Sprafke, T., Fitzsimmons, K.E., Grützner, C., Elliot, A., Marquer, L., Nigmatova, S., 2018. Reevaluation of Late Pleistocene loess profiles at Remizovka (Kazakhstan) indicates the significance of topography in evaluating terrestrial paleoclimate records. Quaternary Research 1-17. doi:10.1017/qua.2017.103

Springer, A., Stevens, L., 2009. Spheres of discharge of springs. Hydrogeology Journal 17, 83-93. doi:10.1007/s10040-008-0341-y

Taimagambetov, Zh.K., 1983. Shulbinskaya stoyanka [Shulbinka site]. Arkheologiya epokhi kamnya i metalla Sibiri. Novosibirsk 161-167.

Taimagambetov, Z.K., 1990. Paleoliticheskaya stoyanka im. Ch. Valikhanova [The Ch. Valikhanova Paleolithic site]. Nauka KazSSR, Alma Ata.

Taimagambetov, Z.K., 1997. Periods in the development of Kazak palaeolithic industries: Their chronology and correlation with the industries in contiguous territories. East and West 47, 351-361.

Taimagambetov, Z.K., 2009. Maibulak-First stratified Paleolithic site in Zhetysu (Kazakhstan). In: Derevianko, A.P., Shunkov, M.V. (Eds.), Drevneǐshie Migratsii Cheloveka v Evrazii: Materialy Mezhdunarodnogo Simpoziuma, (6-12 Sentiabria 2009 g., Makhachkala, Respublika Dagestan, Rossiia) [The Earliest Human Migrations in Eurasia: Proceedings of the International Symposium (Makhachkala, Dagestan Republic, Russia, September 6-12, 2009]. Institute of Archaeology and Ethnography Press, Novosibirsk, pp. 301-309. 
Taimagambetov, Z.K., 2012. The Paleolithic of Eurasia Featuring the Case of the Stratified Site of Shul'binka in Eastern Kazakhstan. Anthropology \& Archeology of Eurasia 51, 79-97. doi:10.2753/AAE1061-1959510104 Taimagambetov, Ž.K., Nokhrina, T.I., 1998. Arheologicheskie kompleksy peshchery Karaungur (Yuzhnyi Kazahstan) [Archaeological complexes from Karaungur Cave (South Kazakhstan)]. Miras, Turkestan.

Taimagambetov, Z.K., Ozherelyev, D.V., 2008. Izuchenie stratifitsirovannoy stoyanki Maibulak v Zhetisu v 20042007 g. [Studies at the stratified site of Maibulak in Zhetisu, 2004-2007]. Miras 1, 70-86.

Taimagambetov, Z.K., Ozherelyev, D.V., 2009. Pozdnepaleoliticheskie pamyatniki Kazakhstana [Late Paleolithic sites of Kazakhstan]. Kazak Un-Ti, Almaty.

Tryon, C.A., 2010. How the geological record affects our reconstructions of Middle Stone Age settlement patterns: the case of alluvial fans in Baringo, Kenya. Settlement dynamics of the Middle Paleolithic \& Middle Stone Age 3, 39-66.

U. S. EPA, 2002. Lexicon of Cave and Karst Terminology with Special Reference to Environmental Karst Hydrology. U. S. Environmental Protection Agency, Office of Research and Development, National Center of environmental Assessment, Washington Office, Washington, DC.

Verachtert, E., Eeckhaut, M., Poesen, J., Deckers, J., 2010. Factors controlling the spatial distribution of soil piping erosion on loess-derived soils: A case study from central Belgium. Geomorphology 118, 339-348. doi:10.1016/j.geomorph.2010.02.001

Viles, H.A., Goudie, A., 1990. Tufas, Travertines and allied carbonate deposits. Progress in Physical Geography 14, 19-41. doi:10.1177/030913339001400102

Voloshin, V.S., 1971. Novye nakhodki kamennego veka v Tsentralnom Kazakhstane [New findings of Stone Age in Central Kazakhstan]. Arkheologicheskie otkrytiya 1970 goda. Moscow.

White, W., 2007. Cave sediments and paleoclimate. Journal of Cave and Karst Studies 69, 76-93.

Zhu, Z., Dennell, R., Huang, W., Wu, Y., Qiu, S., Yang, S., Rao, Z., Hou, Y., Xie, J., Han, J., Ouyang, T., 2018. Hominin occupation of the Chinese Loess Plateau since about 2.1 million years ago. Nature 559, 608-612. doi:10.1038/s41586-018-0299-4

Zwyns, N., Paine, C.H., Tsedendorj, B., Talamo, S., Fitzsimmons, K.E., Gantumur, A., Guunii, L., Davakhuu, O., Flas, D., Dogandžić, T., Doerschner, N., Welker, F., Gillam, J.C., Noyer, J.B., Bakhtiary, R.S., Allshouse, A.F., Smith, K.N., Khatsenovich, A.M., Rybin, E.P., Byambaa, G., Hublin, J.-J., 2019. The Northern Route for Human dispersal in Central and Northeast Asia: New evidence from the site of Tolbor-16, Mongolia. Scientific Reports 9, 1-10. doi:10.1038/s41598-019-47972-1 
1

3

4 